\title{
Pytanie o status (nie)narodzonego dziecka w Starym Testamencie. Wj 21,22-25 jako przypadek szczególny
}

\section{The question of the status of an (un)born child in the Old Testament. Ex 21,22-25 as an exceptional case}

Słowa klucze: płód; narodziny; poronienie; szkody cielesne; lex talionie.

Keywords: foetus; birth; miscarriage; harm; lex talionis.

Streszczenie. Narodziny dziecka wiązane są w Starym Testamencie ze stwórczą działalnością Boga. Moment „prawdy” stanowi chwila narodzin. Wtedy decyduje się czy noworodek może być określony jako dziecko (chłopiec; dziewczynka), czy jako „poroniony płód”. Wj 21,22-25 pozwala jednak sądzić, że we wszystkich fazach od poczęcia do narodzin, płód cieszy się taką samą ochroną prawną, jak dorosły Izraelita.

Abstract. Birth of a child in the Old Testament is connected with the creative activity of God. Giving birth is the moment of truth. Then the new-born child is called either an alive child (a boy or a girl) or a miscarried foetus. Ex 21,22-25 allows us to state that from the conception to birth the foetus is protected by law in the same way as an adult Israelite.

$\mathrm{T}$ emat narodzin człowieka i początków życia, jak zauważa Maria Häusl ${ }^{1}$, podejmowany był w literaturze biblijnej dość rzadko. Rozwój współczesnej wiedzy o początkach życia ludzkiego, nowe technologie w jego inicjowaniu (np. in vitro), medycyna prenatalna, kwestia aborcji, wszystko to prowadzi dziś nieuchronnie do stawiania pytań natury etycznej, jak i refleksji nad statusem

1 Auf den Leib, s. 142. Zmianę tej sytuacji zwiastują m.in. monografie M. Stol, Birth, T.S. Philip, Menstruation, jak i opracowania samej M. Häusl, Die Zeit, s. 69-85; eadem, Geburt, s. 119-134. 
prawnym płodu ludzkiego. W niniejszym artykule chcemy przyjrzeć się poglądom autorów Starego Testamentu, dotyczących kwestii początków życia oraz prawnemu statusowi ludzkiego płodu w prawodawstwie starożytnego Izraela. W tym ostatnim przypadku na szczególną uwagę zasługuje Wj 21,22-25. Analiza tego tekstu w ostatnich latach wykazuje bowiem tendencje do weryfikacji dotychczasowych ustaleń, dotyczących interpretacji treści tego sformułowania prawnego.

Biblijne opisy narodzin zawsze przedstawiają je jako proces naturalny ${ }^{2}$. Niemniej za źródło życia autorzy biblijni zawsze uważają Boga, a ono samo uznawane jest za święte (por. Rdz 9,1-7). Poczęcie i narodziny dziecka postrzega się więc jako owoc błogosławieństwa (Rt 4,14; Łk 1,14.57-58), a samą płodność wskazuje jako jedno z zasadniczych powołań człowieka (Rdz 1,28; 9,1.7). Autorzy biblijni są niezmiennie przekonani, że to Bóg otwiera ( $\operatorname{Rdz} 29,31$; $30,22)$ i zamyka łono kobiety (1 Sm 1,5-6); daje (Rt 4,13) lub zabiera możliwość porodu $(\mathrm{Oz} 9,14)$. Z tego też względu dość często wspomina się boskie zapowiedzi przyszłych narodzin ( $R d z 16,11 ; 17,15-16$; 18,9-15; Sdz 13,3.5; Łk 1,31) . Zwykle informuje się w ten sposób o narodzinach synów (Rdz 30,1; $1 \mathrm{Sm} \mathrm{1),} \mathrm{choć} \mathrm{w} \mathrm{niektórych} \mathrm{przypadkach} \mathrm{istotną} \mathrm{rolę} \mathrm{odgrywają} \mathrm{też} \mathrm{informa-}$ cje o narodzinach córki $(\operatorname{Rdz} 30,21 \rightarrow \operatorname{Rdz} 34$; por. też $\operatorname{Rdz} 22,23 \rightarrow \operatorname{Rdz} 24)$. Naturalne - skądinąd - bóle porodowe, mają w Biblii swoją religijną etiologię (por. Rdz 3,16). Często zresztą wspomina się także o kłopotach podczas porodu (Rdz 25,21-26), a nawet śmierci matki w jego trakcie ( $\mathrm{Rdz} 35,16-20 ; 1$ Sm 4,19-20). Dodając do tego liczne metafory, kojarzące trudności związane z porodem, z różnymi problemami egzystencjalnymi ( $2 \mathrm{Krl} \mathrm{19,3;} \mathrm{Iz} \mathrm{26,17-18;}$ Oz 13,13; Mi 4,9-10; J 16,21; Ap 12,2), łatwo można się domyśleć, że narodziny w czasach biblijnych związane były z doświadczeniem wielkiego ryzyka,

2 Wspomina się akuszerki ( $\mathrm{Rdz} 35,17 ; 38,28$; Wj 1,15-21). Czasem były nimi sąsiadki (por. 1 Sm 4,20; Rt 4,13-17). Niejasny do końca opis z Wj 1,16 sugeruje także dwa kamienie, które podkładano pod nogi rodzącej (por. J. Lemański, Księga Wyjścia [NKBST II], s. 111; M. Stol, Birth, s. 119, rys. 4, przy czym Stol krytycznie ocenia [por. tamże, s. 161 przyp. 93] sugestię A.D. Kilmer, The Brick, s. 211-213, że użycie cegieł (glina) stanowi tzw. placental material, nawiązujący do przekonania, iż człowiek powstał z tej samej materii). Następnie wspomina się przykucnięcie lub klęknięcie podczas porodu (por. 1 Sm 4,19), a w Jr 30,6 mowa jest o kładzeniu rąk na biodrach w trakcie rodzenia. Wreszcie opisuje się też kolejne czynności wykonywane przy dziecku tuż po jego narodzinach (Ez 16,4), jak: odcięcie pępowiny, obmycie z krwi, owinięcie w pieluszki, natarcie solą. W tym ostatnim przypadku chodziło być może pierwotnie o rodzaj jakiegoś rytu apotropaicznego (por. W. Berg, Geburt, 749 ze wskazaniem na G. Binder). Często wspomina się wreszcie o nieobecności ojca w trakcie porodu, któremu dopiero po urodzeniu oznajmiano ten fakt (Hi 3,3; Jr 20,15).

3 D. Zeller, Geburtsankündigung, s. 751-753. 
stąd też często przywoływano je jako obraz i znak sądu (Koh 6,3-5; Ps 58,8; $\mathrm{Oz} 9,14)^{4}$. O szybkich i łatwych porodach wspomina się niezwykle rzadko (Wj $1,19)$ i zwykle traktuje się je wówczas symbolicznie, łącząc z czasem zbawienia (Iz 66,8-14).

\section{Proces narodzin}

Na podstawie wypowiedzi autorów biblijnych, można sądzić, że zakładają on trzy fazy związane $\mathrm{z}$ narodzinami dziecka (poczęcie i rozwój płodu, moment narodzin, po narodzinach). Każda z nich ma swoją specyfikę, a jej odkrycie jest istotne dla poszukiwań odpowiedzi na pytanie postawione w tytule artykułu.

\subsection{Przed urodzeniem}

Najczęściej stosowana formuła biblijna dotycząca narodzin brzmi: „poczęła (rdzeń $h r h)$ i urodziła (rdzeń jld)..” (Rdz 4,1; 16,15-16; 19,37-38; 21,1; Wj 2,2; Sdz 13,24; Rt 4,13; 1 Sm 1,20; 2,21; Łk 1,57; 2,7). Sama w sobie sugeruje ona, że faza prenatalna pojmowana była przez autorów biblijnych jako pierwszy etap życia od poczęcia do momentu narodzin. Studium opisów tej fazy życia oraz języka, jakim posługują się autorzy biblijni, akcentując aktywny udział w poczęciu życia zarówno ojca, jak i matki, znaleźć można w monografii Martena Stola ${ }^{5}$. Kontekst tych wypowiedzi sugeruje, że oprócz opisywania procesów naturalnych zachodzących $\mathrm{w}$ łonie matki, początki życia postrzegano także w wymiarze nadprzyrodzonym. Dla zrozumienia tego, w jaki sposób autorzy biblijni patrzą na tę fazę życia ludzkiego pomocne są szczególnie dwa teksty (Ps 139,13-16; Hi 10,8-12) ${ }^{6}$. Nienarodzony jeszcze płód opisany jest w tych wypowiedziach jako kiljôt ( $\rightarrow$ kiljāh) - „nerki”, 'eșem - „kości” (por. Koh 11,5), "ōr - „skóra”, baśar - „ciało/mięso”, gîdîm - „ścięgna” oraz rûah - „duch/ tchnienie". Chodzi zatem wyraźnie o opisy wskazujące na poszczególne elementy ciała ludzkiego. Zdaniem autorów biblijnych kształtują się ono nie tyle poprzez naturalny wzrost, ile przez „utworzenie” $(q n h)^{7}$, „utkanie” (skk) (Ps

4 M. Stol, Birth, s. 27-48; M. Foskett, Birth, s. 470-471.

5 M. Stol, Birth, s. 5-25.

6 Wskazuje je i omawia M. Häusl, Auf den Leib, s. 143-145.

7 Rdzeń czasem oznacza „nabyć drogą kupna” (Ps 74,2; 78,54), jednak w teologii powygnaniowej przybrał sens „stworzyć” por. F.L. Hossfeld, E. Zenger, Psalmen 101-150, s. 723 . 
139,13; Hi 10,11; por. Prz 8,23) ${ }^{8}$ oraz złożenie poszczególnych elementów w całość (Hi 10,8). W Hi 10,10 obrazowo do tego "tkackiego" opisu dodaje się porównanie do przechodzenia ze stanu płynnego w stały (mleko - ser) ${ }^{9}$. Obok wspomnianego rdzenia qnh używa się tu zresztą także rzemieślniczego rdzenia “śh - „zrobić/wyprodukować” (Hi 10,8). Działania Boga przy poczęciu człowieka opisuje się na podobieństwo pracy tkacza i wytwórcy serów (por. Hi 21,24; Mdr 7,1-6). Do tego imaginacyjnego obrazu dodać trzeba także częste porównania do garncarza kształtującego człowieka z gliny (Hi 10,9; por. Rdz 2,7: proch $)^{10}$. Wreszcie o płodzie jako takim psalmista (Ps 139,16) wypowiada się, używając rdzenia glm, który w formie czasownikowej (Qal) opisuje zwijanie (stąd tł. BT: „w zalążku”), a w formie rzeczownikowej (gōlem $\rightarrow$ hapax legomenon gōlmî), zastosowanej we wspominanym psalmie, oznacza coś skłębionego, nieuformowanego - embrion (stąd tł. BŚP: „,w zarodku”)11. O stwórczych działaniach ze strony Jhwh, który kształtuje człowieka, autorzy biblijni wspominają zresztą nader często, choć zwykle już mniej obrazowo (Ps 33,15; 119,73). Szczególnie wymowny jest Jr 1,5 (por. też Iz 49,1; 46,3), gdzie wskazuje się na stwórczy zamysł Boga odnośnie do konkretnego człowieka i jego roli w życiu, zanim jeszcze pocznie się on w łonie matki. Stwórca „zna” $\left(j d^{c}\right)^{12}$ go i „uświę-

8 Według L. Koehler, W. Baumgartner, J.J. Stamm (red.), Wielki słownik (dalej KBL), t. I, s. 707 i D.J.A. Clines (red.), The Dictionary (dalej DCH), t. VI, s. 153-154 należy rozróżnić skk I - "otaczać opieką" i skk II - „tkać, formować”. Zdaniem M. Häusl (Bedecken, s. 56-61) rozróżnienie takie nie jest jednak pewne i możliwe jest rozumienie tego rdzenia czasownikowego w obecnym miejscu także w sensie „osłaniać/ochraniać”, gdyż na czynności tkackie język hebrajski stosuje także inne, bardziej jednoznaczne określenia ('ṣb - „pleść; por. Hi 10,8; rqm -ktoś formujący/tkający kolorowe tkaniny; por. Ps 139,15 [Pual lub Qal passivum) „uformowany, gdy byłem płodem”). Także lbš - „przyodziewać” (Hi 10,11) sugeruje bardziej czynności opiekuńcze niż tkackie.

9 „Semen, the milk-like substance, is poured into the womb; like cheese it coagulates... in the mother's womb into the embryo, and finally flesh and bones are woven together into 'this knot intrinsicate of life..." Por. D.J.A. Clines, Job, 248 ze wskazaniem dodatkowo na Ps 139,13-16; 2 Mch 7,22-23; potem także Koh 11,5; Mdr 7,1-2; Koran, Sura 22,5; 36,76; 40,69; 80,19; 96,2; Pliniusz, Hist.nat. 7,13; m. 'Abot 3,1. Dalsze konotacje tego obrazu por. Ch. Frevel, Die Entstehung, s. 45-57; D. Bester, Körperbilder, s. 188; A. Tronina, Ksiega, s. 185.

10 J. Lemański, Opis, s. 5-24.

11 „Dem Psalmvers geht es nicht um Details der Entstehung des Menschen, sondern um den Rückgriff auf den zeitlichen Anfang. Von daher ist die Übersetzung 'Embryo' für das zusammengewickelte Formlose gar nicht so falsch" cyt. z Ch. Frevel, O. Wischmeyer, Menschensein, s. 18.

12 Por. Rdz 18,19: Abraham; Wj 33,12.17: Mojżesz; 2 Sm 7,20: Dawid. 
ca"13, co nie powinno być jednak interpretowane jako predestynacja, lecz powołanie (por. Jr 20,18: kryzys).

Podsumowując, człowiek w obu analizowanych opisach w punkcie wyjścia stanowi nieuformowany jeszcze „kłębek”, z którego wyłaniają się poszczególne elementy jego cielesności. Dopiero złożone razem przez Boga (obraz tkania, wytwarzania sera, lepienia/formowania gliny) tworzą one ciało człowieka. Sposób postrzegania tej cielesności splata się tu wyraźnie ze sferą kosmologiczną, gdyż o powstaniu poszczególnych części ciała mówi się w nich w taki sam sposób, jak o stworzeniu pozostałych elementów wszechświata. Opis poczęcie człowieka w łonie matki nie wyklucza wyobrażeń o jego pochodzeniu z głębin ziemi. Oba wspomniane miejsca pozwalają okryć tajemnicą sam akt poczęcia (Ps 139,15; por. Hi 1,21; Koh 11,5).

\subsection{Narodziny}

Narodziny, jako początkowy moment życia człowieka, przywoływane są w Biblii nader często. Część z tych opisów pozwala wydobyć informacje dotyczące poglądów na temat kompleksowego obrazu rodzącego się człowieka (Ps 22,10-11; Hi 3,11.12.16; Lb 12,12; Koh 6,3-5; Ps 58,9; Iz 26,17-18) ${ }^{14}$. Zwraca uwage fakt, że w powyższych tekstach mowa jest przede wszystkim o ciele kobiety. Wymienia się bețen - „łono, brzuch (kobiety z dzieckiem, por. Pnp 7,3; Koh 11,5)”; rehem - „łono”; birkajîm ( $\rightarrow$ berek) - „kolana”; šadajîm ( $\rightarrow$ šad) - piersi matki”; hîl $(\rightarrow h j l)$ - „bóle porodowe”. Główny przedmiot zainteresowania stanowi tu jednak noworodek, który w wymienionych powyżej tekstach nigdy nie jest opisywany w trakcie rodzenia za pomocą słów i obrazów typowych dla zdrowego dziecka (inaczej jest w przypadku bliźniąt, por. Rdz 25,25-26; 38,28-30). Wypowiedzi autorów biblijnych wskazują bowiem, że w trakcie rodzenia może dojść do poronienia lub noworodek tuż po urodzeniu okaże się niezdolny do życia i umrze ${ }^{15}$. Obraz rodzącej w bólach kobiety nader często - o czym wspominaliśmy - przywoływany jest więc w Biblii jako metafora sytuacji kryzysowych ${ }^{16}$. Kobieta $w$ takich sytuacjach określana jest wówczas jako „bezdzietna” (šekôl) z powodu utraty dziecka, sam taki fakt nazywa się "poronieniem” (jôssè t), natomiast utracone dziecko „poronionym płodem” (nēpel; Ps 58,9; Hi 3,16; Koh 6,3). Kontekst zastosowania tego rodzaju słownictwa i wszystkich tego rodzaju sytuacji stanowi fakt nagłego, dramatycznego

Por. G. Fischer, Jeremia, s. 134.

Teksty te proponuje i omawia M. Häusl, Auf den Leib, s. 145-148.

M. Häusl, Geburt, s. 127-130.

Por. M. Häusl, Bilder, s. 86-112; C. Bergmann, Childbirth. 
poronienia, ze wszystkimi tego skutkami w wymiarze cielesnym, społecznym i transcendentnym ${ }^{17}$. Szczególnego dramatyzmu nabiera opis zagrożonego śmiercią dziecka w Lb 12,12, gdzie obraz jego martwego ${ }^{18}$ ciała opisany jest

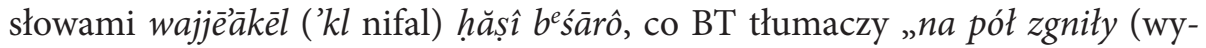
chodzi z łona swej matki)”, a BŚP: „na wpół rozłożony”. Bardziej dosłownie oddaje sens tych słów Anna Kuśmierek ${ }^{19}$ : „i (jest) zżarte (na) pół ciało jego” ${ }^{20}$. W Ps 58,9 poronienie zestawione jest $\mathrm{z}$ kolei z pełzaniem ślimaka. Tak chyba należy w obecnym miejscu tłumaczyć słowo šabbelûl, które w starożytnych przekładach często przybiera jednak sens „wosk”21. Maria Häusl ${ }^{22}$ sugeruje porównanie obu obrazów z w. 9 jako przykład rozejścia się części ciała. Konkluzja nie jest jednak chyba trafna. Klaus Seybold ${ }^{23}$ komentuje tę wypowiedź następująco: „Tekst nie jest całkowicie pewny ani jasny”. Porównanie skutków przekleństwa (ww. 7-10) w jego opinii odnosi się tu m.in. do „ślimaka, który... rozpuszcza się w swoim śluzie” oraz poronionego płodu, embrionu, który nigdy nie ujrzy światła słonecznego. Chodzi więc, jego zdaniem, o dwa różne przykłady, które stanowią „Bilder des Untergangs und der Vernichtung”. Z drugiej strony część manuskryptów oraz tłumaczenie Symmacha (chorion - „poronienie") pozostawia niepewność, czy aby w pierwszej części w. 9, podobnie jak w drugiej, także nie chodzi o „poroniony płód” 24 oraz nawiązanie do w. 4 (łono matki). Wtedy sugestia wspomnianej autorki rzeczywiście mogłaby być słuszna, tyle że zniknąłby obraz ślimaka i to poroniony płód opisany byłby najpierw jako rozkładające się ciało, a potem jako martwy byt niemogący ujrzeć światła słonecznego (por. Hi 3,11.16; Koh 3,3b-5; 6,4-5). Formuła „z ciemności w światłość" stanowi na starożytnym Bliskim Wschodzie jedną z popularniejszych metafor opisujących narodziny żywego dziecka ${ }^{25}$. W samym Starym Testamencie zresztą światło generalnie również jednoznacznie kojarzy się

17 Por. M. Häusl, Auf den Leib, s. 147 przyp. 67.

18 W tekście użyte jest słowo mēt - „martwy” (człowiek), jednak kontekst sugeruje sens „martwy płód” (tak LXX: ektrōma; ang. stillbirth” por. B.A. Levine, Numbers, 333). H. Seebass (Numeri, 58) zachowuje jednak dosłowny sens: „wie ein Toter”.

19 Hebrajsko-polski, s. 576.

20 Por. H. Seebass, Numeri, s. 58: „...die Hälfte seines Fleisches... verzehrt ist”; B. Levine, Numbers, s. 315: „... with half of his body eaten away!”.

21 Por. KBL, t. II, s. 404.

22 Por. M. Häusl, Auf den Leib, s. 147.

23 Die Psalmen, s. 233.

24 Tak tłumaczą ten wiersz np. F.L. Hossfeld, E. Zenger, Psalmen 51-100, s. 131 oraz zob. komentarz s. 133.138 .

25 K. Volk, Vom Dunkel, s. 91. 
z udanym życiem (por. Ps 13,4; 18,29; Hi 18,5-7; 33,28.30). Z drugiej strony warto również zauważyć, że autorzy biblijni nie opisują rodzącego się dziecka wyłącznie z perspektywy jego matki, czy zewnętrznych obserwatorów. Często mowa jest bowiem nie tylko o jego zrodzeniu, lecz także o tym, że ono samo „wychodzi” (jṣ’) z łona matki (Lb 12,12; Rdz 38,29; Jr 1,5; 20,18; Hi 1,21; 3,11; 38,8.29; Koh 5,14; Syr 40,1), co - jak słusznie zauważa M. Häusl ${ }^{26}$ - opisuje narodziny z perspektywy noworodka. W ten sposób podkreśla się zarazem ruch, jedną z elementarnych, obok oddychania, cech żywego stworzenia. Narodziny są więc początkiem tego, co w Biblii określa się życiem (hjh), a wspomniana badaczka dookreśla je wręcz mianem gelingenden Leben - „udanym życiem”.

Wymienione na początku teksty sugerują, że narodziny stanowią swego rodzaju moment prawdy, w którym decyduje się to, co lub kto się narodzi. Może to być zdrowy chłopiec lub dziewczynka, ale także słaba istota, ktoś urodzony przedwcześnie, w niewłaściwym czasie, płód poroniony, niewłaściwy owoc matczynego łona ${ }^{27}$. W Iz 26,18 porównuje się takie sytuacje do zrodzenia wiatru. Słowo „wiatr” oznacza tu „nicość”, „brak wartości”28 tego, co ostatecznie zrodziło się w wyniku bóli porodowych. Owoc tego, co się poczęło, ocenia się więc w momencie narodzenia (por. Iz 33,11; 59,4; Hi 15,35). Takiemu rozumieniu sprzyja również zastosowanie stałych formuł mērehem i mibețen, które z jednej strony mogą oznaczać wspominany już początek życia $\left(m i[n]-r a h m+j s^{\prime}\right)$, jak i jego przedwczesny koniec $(m i[n]-r a h m m \hat{u} t)$. W tym drugim wypadku może chodzić o celowe odwrócenie pierwszej z formuł ${ }^{29}$, aby pokazać, że moment kojarzony normalnie z początkiem życia, stał się ostatecznie momentem jego przedwczesnego końca. Samo zestawienie wyrażeń opisujących początek życia (merehem i mibețen) z oznaczającym jego koniec słowem mût, jest nader częste ${ }^{30}$. W Lb 12,12 i Hi 3,11 takie zestawienie ma charakter szczególnie ostrego przeciwstawienia. W pierwszym wypadku Miriam porównana jest do noworodka, w którym nie ma życia (haj), gdyż jest martwe $(m \bar{e} t)$, a w drugim Hiob stawia dramatyczne pytanie, zastanawiając się z wyraźnym bólem, czemu nie był martwy ( $m \hat{u} t)$, gdy wychodził z łona matki ${ }^{31}$.

26 Aufden Leib, s. 147.

27 M. Häusl, Auf den Leib, s. 147.

28 Por. W.A. Beuken, Jesaja, s. 380.

29 M. Grimm, Dies Leben, s. 84.

30 M. Grimm (Dies Leben, s. 80-84) wskazuje je w przypadku mērehem na teksty z Lb 12,12; Iz 46,3; 49,15; Jr 1,5; 20,17.18; Ps 22,11; 58,4; 71,6; 110,3; Hi 3,11; 10,18; 38,8, zaś w przypadku mibețem na teksty z Sdz 13,5.7; 16,17; Iz 44,2.24; 46,3; 48,8; 49,1.5; Ps 22,10-11; 58,4; 71,6; Hi 1,21; 3,11; 10,19; 31,18; 38,29; Koh 5,14.

31 M. Häusl, Auf den Leib, s. 148. 
Warto zwrócić uwagę, że w obu przypadkach chodzi o osoby jeszcze żyjące, ale znajdujące się w sytuacjach, które - zwłaszcza w przypadku Hioba - z udanym życiem trudno jest kojarzyć.

\subsection{Po urodzeniu}

Pierwsze chwile po urodzeniu opisuje przede wszystkim metaforyczna wypowiedź z Ez 16,4-6 (por. też Hi 1,21) ${ }^{32}$. Obraz dziewczynki porzuconej tuż po narodzeniu służy tu prezentacji kondycji Izraela w chwili jego narodzin. Opuszczone i pozbawione właściwej opieki niemowlę skazane jest na śmierć. JHWH okazuje mu jednak swoją litość i bierze je pod opiekę. Chodzi o czas poprzedzający osiągnięcie przez dziewczynkę dojrzałości płciowej (Ez 16,7). Kwintesencją całej wypowiedzi jest zatem boskie: „żyj!” (w. 6: hjh). Matka niejako reprezentuje tu Boga, a jej działania wobec noworodka są tymi, które służą opiece nad ofiarowanym przez Niego nowym życiem. Kontekst wskazuje, że to życie wymaga opieki, gdyż nowo narodzone dziecko (dziewczynka) nie jest zdolne żyć samodzielnie. Pierwsze czynności po przyjściu na świat (Ez 16,4), których w rozpatrywanym przypadku odmówiono noworodkowi, to odcięcie pępowiny ( $\check{s} o ̄ r)$ i obmycie jego ciała $\mathrm{z}$ krwi. W obecnym miejscu sens hebrajskiego słowa šōr - „pępowina” jest jasny, inaczej niż w przypadku Prz 3,8, gdzie możliwy jest sens „pępek”, „ciało” lub „siła cielesna”33. Wypowiedź Hioba (Hi 1,21) ze swej strony podkreśla nagość w momencie urodzenia (por. Oz 2,5; Koh 5,14). Obraz służy tu opisowi stanu posiadania tak w momencie narodzin (Hi 3,10-11), jak i w momencie śmierci (Ps 139,13) ${ }^{34}$. Wprowadza zarazem rozwijany później temat człowieka jako śmiertelnika, który powstaje z prochu i doń powraca (Hi 4,19; 17,16; 42,6; Rdz 3,19) ${ }^{35}$. Powala jednak zarazem wykazać ścisłą relację pomiędzy ciałem (skórą; por. Hi 2,4) a ubraniem ${ }^{36}$. Choć nagość jest naturalnym stanem ludzkiego ciała, to w kontekście społecznym, ciało to powinno tuż po urodzeniu zostać przyodziane (Ez 16,4: ht - infinitivus absolutus Hofal + perfectum Pual $\mathrm{z}$ negacją $=$ „W pieluszki nie zostałaś owinięta/otulona”). Zadanie to należy w pierwszym rzędzie do matki dziecka lub innych członków społeczności obecnych przy jego narodzeniu. W dalszym ciągu dziecko będzie karmione piersią (por. '̂̂l - „niemowlę" $\rightarrow$ ' $w l$ II - „karmić

\footnotetext{
32 Teksty oraz ich omówienie proponuje M. Häusl, Auf den Leib, s. 149-150.

33 Por. KBL, t. II, s. 599; C.L. Rogers, šōr, s. 249-250.

34 „W formie przysłowia wyraża przekonanie, że posiadłości człowiek zdobywa w trakcie życia. Rodzi się z niczym i z niczym odchodzi” cyt. A. Tronina, Księga, s. 106.

35 N.C. Habel, The Book, s. 93.

36 D. Bester, Körperbilder, s. 253-254.
} 
piersią"37; jnq - „karmić piersią, pielęgnować”38). Stan ten trwał czasem aż do trzeciego roku życia $(2$ Mch 7,27) lub nawet dłużej (por. 1 Sm 1,22-23), a dzień zaprzestania tej czynności fetowany był jako wielka uroczystość $(\operatorname{Rdz} 21,8)^{39}$. Noworodek, opuszczając łono matki, wymaga więc opieki ze strony dorosłych, ale zarazem od razu zyskuje status nowego członka wspólnoty rodzinnej. Symbolicznie wyrażają to najpierw piersi i kolana matki (por. Rdz 30,3). Czasem mowa jest też o posadzeniu dziecka na kolanach u ojca (wyraz akceptacji w rodzinie; por. Rdz 48,12; 50,23; Hi 3,12; Iz 66,12). Znaczenie wspominanego już „natarcia solą” nie jest do końca jasne. Egzegeci z jednej strony widzą tu rodzaj czynności higienicznej, mający na celu oczyszczenie i wzmocnienie skóry dziecka, praktykowane zresztą czasem do dziś wśród Arabów, używających mieszanki soli i oliwy ${ }^{40}$, a z drugiej sugerują czasem pierwotny, apotropaiczny sens tej czynności (strzeże noworodka przed demonami) ${ }^{41}$.

\subsection{Wnioski}

W przeanalizowanych powyżej wypowiedziach autorów biblijnych wyraźnie przebija się przekonanie, że przed narodzinami dziecka, początek życia i kształtowanie się jego ciała łączone jest ze stwórczymi działaniami Boga. Stwórca „powołuje” człowieka, zanim pocznie się on w łonie swej matki. Poczęcie i prenatalny etap życia opisuje się za pomocą metafor (tkanie, wytwarzanie sera, kształtowanie gliny/prochu). Dla autorów biblijnych jest to faza ukrytego dla oczu działania Boga. Zastosowane metafory pozwalają postrzegać cały proces jako łączenie i nadawanie kształtu poszczególnym członkom ciała. Moment narodzin opisywany jest jako przejście z ciemności do światła i początek właściwego, „własnego” życia poczętego wcześniej dziecka, o ile jednak noworodek urodzi się zdolnym do takiego życia. To swoisty moment prawdy i napięcia pomiędzy życiem a śmiercią. Nowo narodzone dziecko ocenione jest bowiem czasem także jako „poroniony płód” lub w ogóle nie nazywa się noworodka dzieckiem. W pierwszych chwilach i latach po narodzinach dziecko nadal potrzebuje troskliwej opieki, głównie ze strony matki. Moment przełomowy stanowi dzień „odstawienia od piersi”, kiedy dziecko rozpoczyna nową fazę swojego życia.

\footnotetext{
37 KBL, t. I, s. 746.

38 Ibidem, s. 394.

39 Na ten temat por. J. Lemański, Księga Rodzaju, s. 447.

40 M. Greenberg, Ezechiel, s. 331.

41 D.I. Block, The Book, s. 475.
} 


\section{Wj 21,22-23(-25): przypadek szczególny}

Przepis prawny pojawiający się w kontekście tzw. Kodeksu Przymierza - najstarszego zbioru prawnego w Starym Testamencie - dość często przytacza się w dyskusji związanej z kwestią aborcji ${ }^{42}$. W kontekście tego przepisu nasuwa się bowiem kilka istotnych pytań: czy płód uważany jest tu za pełnoprawną osobę? Czy jego ewentualna śmierć uważana jest za zabójstwo i domaga się zemsty czy tylko rekompensaty finansowej? Czy w takim samym stopniu, jak do dorosłej osoby, odnosi się do niego zasady talionu? Zwykle intepretuje się interesujący nas przepis $\mathrm{w}$ świetle innych starożytnych praw $\mathrm{z}$ Bliskiego Wschodu, poświęconych podobnej sytuacji. Sugeruje się tym samym, że autor biblijny miał na uwadze dokładnie te same zasady i tekst biblijny w tym wypadku należy rozumieć dokładnie tak samo, jak sformułowania paralelnych do niego ustaleń prawnych $\mathrm{z}$ tego regionu ${ }^{43}$. Słownictwo $\mathrm{z}$ Wj 21,22-23 jest jednak dwuznaczne i w wielu wypadkach można mieć uzasadnione wątpliwości, czy rzeczywiście należy je rozumieć dokładnie tak, jak sugerują to wspomniane paralele pozabiblijne. $\mathrm{Z}$ tego też powodu w ostatnim okresie analiza egzegetyczna tego tekstu prowadzi do różnych konkluzji, a w konsekwencji do odmiennych tłumaczeń. Nie mamy więc pewności, czy w interesującym nas przypadku czasownik jṣ’ rzeczywiście należy rozumieć jako poronienie, czy też raczej jako przedwczesne urodzenie, a nawet normalny poród i ocenę ewentualnych konsekwencji, jakie urodzone potem dziecko poniosło w wyniku opisanej wcześniej bójki. Nie mamy też powodów, aby sądzić, że poszkodowana kobieta jest żoną jednego z jej uczestników. Nie wiemy, jaki jest właściwy sens i odniesienia dla słowa 'āsôn ${ }^{44}$, ani jak tłumaczyć zwrot biplilîm? Wreszcie spory budzi także to, jak do całego przypadku należy odnieść cytowane po nim lex talionis ((Wj 21,23b-25)? Od ustalenia tych kwestii zależy odpowiedź na pytanie, czy słuszne jest przekonanie o tym, że „Wyjścia 21,22-23 odnosi się do prawnego statusu i ekonomicznej wartości płodu" ${ }^{45}$ ?

42 M.in. G. Kline, Lex Talionis, s. 193-201; H.W. House, Miscarriage, s. 108-123; J.M. Sprinkle, The Interpretation, s. 233-253; M. Parchem, Aborcja, s. 485-509.

43 Por. np. R. Westrbrook, Lex Talionis, s. 52-69.

44 Por. np. J. Ellington, Miscarriage, s. 336.

45 Th.B. Dozeman, Exodus, s. 534; por. J. Lemański, Księga Wyjścia (PKB), s. 191. 


\subsection{Paralele}

Aby zrozumieć tradycyjną interpretację przepisu z Wj 21,22-25, należy najpierw spojrzeć na starożytną tradycję prawną, która dotyczy podobnego zagadnienia. Do niej bowiem odwołują się jej zwolennicy. Najczęściej przytaczane paralele $^{46}$ do Wj 21,22-25 są następujące:

Sumeryjskie Prawa Lipid-Isztara (Kol. III, 2-6.7-8.9-13) ${ }^{47}$ :

Jeśli [ktoś] pobił czyjąś córkę i ona utraciła swój płód, zapłaci 1/2 miny srebra ((Kol. III, 2-6)

Jeśli umarła, człowiek ten zostanie z [abity] (Kol. III, 7-8).

Jeśli [ktoś] pobił czyjass niewolnice i ona utraciła swój płód, zapłaci 5 szekli srebra (Kol. III, 9-13).

Sumeryjska tabliczka z ćwiczeniami z prawa niejakiego Belszunu (YBC 2177 $\$ \$ 1-2)^{48}$ :

Jeśli [ktoś] nieumyślnie potracit córkę obywatela, która $z$ tego powodu straciła swój płód, zapłaci 10 szekli srebra $(\$ 1)$.

Jeśli [ktoś] pobił córkę obywatela, która $z$ tego powodu straciła swój płód, zapłaci $1 / 2$ miny srebra (czyli 20 szekli) $(\$ 2)$.

Prawo Hammurabiego (KH $₫ 209-210$, w dyskusji uwzględnić należy tė̇ $\$ \$ 211-214)^{49}$.

Jeśli obywatel córke obywatela uderzył i sprawił, że płód swój poroniła, 10 szekli srebra za płód jej zapłaci (\$209).

Jeśli kobieta ta zmarła, córkę jego zabija (\$210).

Prawo średnioasyryjskie (II A 21.50-53) ${ }^{50}$ :

Jeśli ktoś uderzył córkę obywatela i spowodował, że utraciła swój płód, i wniesiono skarge przeciw niemu i uznano go za winnego, zapłaci 2 talenty i 30 min ołowiu, wymierzy mu się 50 kijów i będzie on petnił służbę królewska przez cały miesiac (\$21).

[Jeśli ktoś] uderzył [żonę] obywatela i spowodowat, że utraciła [swój płód, człowiek, który spowodował, że] żona obywatela [utraciła swój] płód, będzie po-

46 Por. np. W.H.C. Propp, Exodus, s. 226-227.

47 O. Kaiser (red.), Texte (dalej TUAT), t. II/1, s. 25-26; polskie tłumaczenie E. Lipiński, Prawa, s. 84.

48 A.T. Clay, Miscellaneous, nr 28; M.T. Roth (red.), Law, s. 43; polskie tłumaczenie E. Lipiński, Prawo, s. 62 ze wskazaniem na C. Kunderewicz, Najstarsze, s. 41-42.

49 TUAT, t. I/1, s. 69; M. T. Roth (red.), Law, s. 122-123; polskie tłumaczenie M. Stępień (tł.), Kodeks (dalej KH), s. 124.

50 TUAT, t. I/1, s. 83.91; M. T. Roth (red.), Law, s. 160.173-174; polskie tłumaczenie E. Lipiński, Prawo, s. 179 (\$21), 191-192 (\$\$50-53). 
traktowany tak, jak on ja potraktował; [za] jej płód zapłaci petna cene życia. I jeśli kobieta ta umarła, zabija mężczyznę, za jej płód zapłaci pełna cenę życia. A jeśli mąż tej kobiety nie ma syna i jego żona, zostawszy uderzoną, utraciła swój płód, za jej płód zabija tego, co uderzyt. Jeśli płód jej był córką, zapłaci tylko pełna cenę życia (\$ 50).

Jeśli ktoś uderzył żonę obywatela, która nie dochowuje swych dzieci, i spowodowat, że utraciła swój płód, za kare zapłaci 2 talenty ołowiu (\$51).

Jeśli ktoś uderzył prostytutkę i spowodował, że straciła swój płód, wymierza mu cios za cios, zaptaci petna cenę życia (\$52).

Jeśli kobieta samowolnie pozbyła się swego płodu [i] wniesiono przeciw niej skarge [i] uznano ja za winna, wbije się ja na pal [i] nie pogrzebie się jej. Jeśli zmarła $w$ trakcie aborcji, wbije się ja na pal [i] nie pogrzebie się jej. Jeśli ukryto tę kobietę, ponieważ pozbyła się swego płodu, $i$ [nie] doniesiono tego [...] (\$53). Prawo hetyckie $(\$ \$ 17-18)^{51}$ :

Jeśli ktoś spowoduje u obywatelki poronienie, [jeśli] to jest jej dziesiąty miesiąc, zapłaci 10 szekli srebra, jeśli to jest jej 5 miesiac, zapłaci 5 szekli srebra, będzie dogladat za to jej domu ( $\$ 17)$.

Jeśli ktoś spowoduje, że niewolnica poroni, jeśli to jest jej 10 miesiąc, zapłaci 5 szekli srebra (\$18).

Przytoczone przepisy charakteryzuje kilka istotnych rozróżnień w ocenie „szkód” i w konsekwencji w ustaleniu wysokości kary. Rozróżnia się zatem to, czy kobieta jest wolną obywatelką, czy niewolnicą lub nierządnicą; czy stracone dziecko to chłopiec czy dziewczynka; czy było to przypadkowe potrącenie, czy raczej świadome uderzenie; czy mąż tej kobiety ma już syna, czy nie, a wreszcie także to, jak daleko zaawansowana była ciąża. Tego rodzaju różnic nie znajdujemy jednak $\mathrm{w}$ interesującym nas tekście biblijnym, a przynajmniej nie mówi się o nich wprost.

Obrońcy tezy, że przepis prawny z Wj 21,22-23(-25) należy interpretować paralelnie do wymienionych powyżej przepisów, zwłaszcza tych z prawodawstwa mezopotamskiego, mają jednak dwa dobre argumenty ${ }^{52}$. Pierwszym jest fakt, że w Kodeksie Hammurabiego (dalej KH) znajdujemy paralelne sformułowanie podobnego kazusu ( $\mathrm{KH} \$ \$ 209-210$ ), a ponadto pojawia się ono nawet w podobnej kolejności (por. KH $\$ \$ 206-208$; por. Wj 21,18-19), a więc po wskazaniach dotyczących zapłaty za rekonwalescencję ofiary pobicia. Drugi ar-

51 TUAT, t. I/1, s. 100; M. T. Roth (red.), Law, 219; tłumaczenie własne na podstawie wersji angielskiej.

52 E. van Staalduine-Sulman, Between, s. 222. 
gument, to żydowska tradycja interpretacyjna ${ }^{53}$. Sugerując się więc wnioskami z najnowszych dostępnych mi komentarzy ${ }^{54}$, przyjąłem wcześniej założenie, że w biblijnym sformułowaniu z Wj 21,22 chodzi o przypadek poronienia w wyniku przypadkowego (nieumyślnego) uderzenia podczas bójki ${ }^{55}$. Podobnie zresztą oddaje się rdzeń jṣ̣' w BT, BŚP oraz tłumaczeniu interlinearnym ${ }^{56}$. Inaczej oddał natomiast sens tego rdzenia Stanisław Łach $^{57}$, tłumacząc go: porodziła przedwcześnie. Za zmianą sugerowana przez tego ostatniego autora, jak i w ogóle przeformułowaniem całego tłumaczenia oraz rozumienia Wj 21,22-25, przemawiają dziś nowe argumenty egzegetyczne. Z jednej strony wykazuje się obecnie alternatywne rozumienie lingwistycznych „dwuznaczności” tekstu biblijnego, uwzględniając wnioski płynące $\mathrm{z}$ analizy jego bezpośredniego kontekstu, a z drugiej kwestionuje się zarazem stosowaną mechanicznie zasadę paralelności pomiędzy prawami biblijnymi i prawodawstwem starożytnego Bliskiego Wschodu ${ }^{58}$. Przeanalizujmy zatem te nowe argumenty.

53 S.E. Loewenstamm, Exodus, s. 352-360.

54 Mam tu na myśli przede wszystkim następujące komentarze: C. Houtman, Exodus, t. III, s. 160-171 oraz wcześniejsze opracowanie tego autora Eine schwangere, s. 381-397; Ch. Dohmen, Exodus, s. 140.165. Podobne tłumaczenia znajdujemy zresztą w wielu wcześniejszych komentarzach (M. Noth. B.S. Childs, J. Scharbert). Taki sens powraca też w niektórych nowszych komentarzach. Dla przykładu Th.B. Dozeman,(Exodus) tłumaczy and they bring forth her child, but there is no deadly accident (s. 516). W komentarzu (s. 534) przyznaje potem, że sformułowanie jest dwuznaczne (przedwczesny poród lub poronienie), ale ostatecznie konkluduje, że sens musi być tu identyczny, jak w innych prawach starożytnego Bliskiego Wschodu. M. Priotto (Esodo) także zachowuje w swoim tłumaczeniu dosłowny sens rdzenia jṣ' (s. 404): cosicché ne esca il bambino, ale w komentarzu (s. 432) rozumie to już jako un aborto spontaneo, a więc poronienie.

55 Por. J. Lemański, Księga Wyjścia (NKBST II), s. 459-460; Księga Wyjścia (PKB), s. 191.

56 A. Kuśmirek (tł.), Pięcioksiąg, s. 292.

57 Ksiega Wyjścia, s. 212.

58 Istnieją oczywiście paralele na poziomie tematycznym. Dla przykładu kwestia wypasu na polu sąsiada (Wj 22,4; KH \$\$ 57-58; por. J. Lemański, Księga Wyjścia [NKBST II], s. 473), ale inna jest kara i podział na kategorie (przed żniwami i po żniwach); znane jest prawo dotyczące sytuacji, gdy syn uderza swego ojca (KH § 195), ale nie nakazuje się ucięcia mu ręki, ale klasyfikuje się taki przypadek jako przestępstwa zasługujące na śmierć (por. Wj 21,15; por. J. Lemański, Księga Wyjścia [NKBST II], 458). Prawodawca biblijny wydaje się więc bardziej uogólniać poszczególne kazusy, tak, aby mieściła się w nich szeroka gama przypadków (tak słusznie E. van Staalduine-Sulman, Between, s. 223). 


\subsection{Kontekst}

W ramach tzw. Kodeksu Przymierza, Wj 21,22-25 to kolejny przypadek wtrącenia przerywającego sekwencję tematyczną. Wcześniej podobny przypadek stanowił już przepis z Wj 21,16 (porwanie człowieka), który został umieszczony pomiędzy wskazaniami dotyczącymi złego traktowania rodziców (Wj 21,15.17). Teraz zaś podobnie umiejscowiony zostaje przypadek dotyczący ciężarnej kobiety, który znajduje się pomiędzy prawami dotyczącymi złego traktowania niewolników (Wj 21,20-21.26-27). Dodatkowo kazus ten łączy się z tzw. lex talionis (prawo zęba) ${ }^{59}$. W Pięcioksięgu taka zasada powraca trzykrotnie, ale za każdym razem w połączeniu z innym kazusem prawnym. W obecnym kontekście słownictwo obecne w tej formule prawnej (oko, ząb) nawiązuje do okalających ją wskazań związanych z traktowaniem niewolników (por. Wj 21,26-27). W Kpł 24,17-22 pojawia się po rozstrzygnięciach dotyczących bluźnierstwa (Kpł 24,10-16), a w Pwt 19,15-21 powiązane jest z przypadkiem fałszywego świadectwa. Sytuacja blisko powiązana z obecnym kontekstem powraca raz jeszcze w Pwt 25,11-12. Tam chodzi jednak o kobietę będącą żoną jednego z uczestników bójki, która wtrąca się do niej i - wspomagając swego męża - chwyta jego przeciwnika za genitalia. Prawo nakazuje w takiej sytuacji „obciąć jej rękę"60. W obecnym miejscu kobieta i poczęte w jej łonie dziecko wydaje się być przypadkową ofiarą bójki. Zastosowanie tu lex talionis przy tradycyjnej interpretacji (grzywna za poroniony płód; zasada $\dot{z} y c i e ~ z a \dot{z} y$ cie, $z a ̨ b z a z a b \ldots \mathrm{w}$ przypadku szkód poniesionych przez kobietę) odnosiłoby się tylko do kary równoważącej ewentualne urazy odniesione przez kobietę. Jeśli jednak chodzi nie tyle o poronienie, ile przedwczesne urodzenie dziecka lub ewentualne szkody przez nie poniesione i odkryte już po urodzeniu (także jeśli poród odbył się w normalnym czasie!), to zasada ta mogłaby równie dobrze odnosić się także do niego.

Problematyczny jest również szerszy kontekst. Kodeks Przymierza jest zbiorem różnych praw i przypadków w tych prawach rozstrzyganych. Ich ze-

59 Reguła prawna: życie za życie, oko za oko, ząb za ząb... znana już w Kodeksie Hammurabiego, miała na uwadze przede wszystkim zachowanie proporcji (kara równoważąca skutki czyjejś winy) i przeciwdziałanie przekraczaniu granic w szukaniu zemsty. Wyznaczała więc wyższe standardy i w pewnym sensie stanowi o wyższej jakości w egzekwowaniu sprawiedliwości. Poszkodowany może bowiem na jej podstawie domagać się od sprawcy substytutu utraconej osoby lub poniesienia ekwiwalentnej kary. Ponadto, jak ujął to W.F. Albright (History, 74): „lex talionis... is the principle of equal justice for all”. Zasada ta rzadko jednak była brana pod uwagę dosłownie i jeszcze rzadziej, o ile w ogóle, stosowano ją w praktyce (przypadek szczególny to $\mathrm{Sdz}$ 1,6-7).

60 Użyty jest jednak rzeczownik kap, a nie jād por. KBL, t. I, 463: „dłoń”. 
stawienia polegają często nie tylko na logice tematycznej, ale i na wielu zupełnie innych powiązaniach. Z tego wynika kłopot $\mathrm{z}$ odkryciem rzeczywistej intencji niektórych sformułowań. Układ kolejnych praw w ich bezpośrednim kontekście pozwala zachować jedność tematyczną: rany cielesne, oraz porządek: mężczyźni, niewolnicy, kobiety (por. Wj 21,18-19.20-21.22-25). W tym ostatnim przypadku chodzi jednak o jeden z wariantów, gdyż np. Dekalog ma także kolejność mężczyzna, kobieta, niewolnik (Pwt 20,17), a Kodeks Przymierza: mężczyzna, kobieta, dziecko, niewolnik (Wj 21,28-32; por. $1 \mathrm{Sm}$ 15,3). Prawa związane z zabójstwem wydają się tu podlegać rozróżnieniu: intencjonalne i nieintencjonalne. Jeśli chcemy je zachować, to reguła z Wj 21,23 (życie za życie) sugeruje, że jednak całe zajście może być rozumiane jako intencjonalne. Należy też postawić sobie pytanie: czemu lex talionis zostaje zaaplikowane akurat do interesującego nas kazusu, a nie pojawia się np. już po Wj 21,12? W obecnym przypadku, jak słusznie zauważa, stawiając to pytanie E. van Staalduine-Sulman $^{61}$, jeśli pierwszą część zasady talionu odnieść do śmierci płodu, to powstaje niekonsekwencja, gdyż w pozostałych wypadkach, kiedy mowa jest o śmierci, to używa się zawsze rdzenia czasownikowego $m w t$ (Wj 21,12.18.20.28.29.35; $22,1.10$ ), a ponadto reszta możliwych wariantów (Wj 21,24-25) miałaby się nijak do takiego rozumienia. Jeśli zaś zasada dotyczy tylko kobiety, to czemu nie ma mowy o tym wprost. Ponadto śmierć kobiety nie jest traktowana w Kodeksie Przymierza inaczej niż śmierć mężczyzny, podobnie jak śmierć chłopca lub dziewczynki (por. Wj 21,28-29.31). Badaczka słusznie wnioskuje - co potwierdzimy za chwilę, analizując znaczenie rdzenia czasownikowego jṣ’, że w interesującym nas przepisie nie chodzi o poronienie ${ }^{62}$, ani rozróżnienie: grzywna za poronienie $\leftrightarrow$ zasady talionu za szkody cielesne ze śmiercią na czele w odniesieniu do kobiety ${ }^{63}$.

Drugie pytanie ${ }^{64}$ związane $z$ kontekstem brzmi: czemu rozpatrywany przez nas kazus został umieszczony pomiędzy przepisami dotyczącymi niewolników? Mimo, że często porównuje się strukturalny układ Kodeksu Przymierza do innych zbiorów prawnych starożytnego Bliskiego Wschodu, to jednak takie podejście, jest nie do końca właściwe - uważa E. van Staalduine-Sulman ${ }^{65}$. W obecnym kontekście chodzi generalne o najsłabszych członków społeczności, a kolejność przepisów podlega logice: ich życie, rany cielesne, własność.

61 Between Legislation, s. 208.

62 C. Houtman (Exodus, t. III, 160) tłumacząc go słowem miscarriage, dokonuje dopowiedzenia w tekście: w. 23 „life for life”, w. 24 „(in other cases) an eye for eye...”.

63 Tak C. Houtman, Exodus, t. III, s. 169.

64 E. van Staalduine-Sulman, Between, s. 209.

65 Omówienie i uwagi krytyczne w: Between, s. 209-211. 
W kodeksach spoza Izraela priorytety są zupełnie inne: własność, prawo rodzinne, rany cielesne, niewolnicy ${ }^{66}$. Układ praw w Kodeksie podporządkowany jest najpierw zasadzie tematycznej (principle of topic), a potem o ich kolejności decyduje zasada uporządkowania według priorytetów i obowiązujących zwyczajów kulturowych (principle of priority and cultural assumption) ${ }^{67}$. Kara śmierci zależy od tego, czy jest się bezpośrednio, czy pośrednio winnym czyjejś śmierci (por. Wj 21,12-17). Sekwencja praw dotyczących ran cielesnych polega zasadzie: człowiek zraniony przez człowieka, przez zwierzę i vice versa, zwierzę zranione przez inne zwierzę (Wj 21,18-36). Zachowuje się priorytety: mężczyzna przed kobietą $(21,28)$, syn przed córką (Wj 21,31), niewolnik przez niewolnicą (Wj 21,32) itp. ${ }^{68}$. Strukturalny układ kontekstu, w jakim znajduje się interesujące nas prawo, zdradza jeszcze jedną zasadę, którą kierowali się kompilatorzy/redaktorzy Kodeksu Przymierza: są nią priorytety teologiczne (teological priorites). W połączeniu z zasadą cultural assmuption, wyjaśnia to, czemu kazus ciężarnej kobiety znalazł się pomiędzy przepisami dotyczącymi niewolników. Zdaniem cytowanej przez nas autorki ${ }^{69}$, obecny mini-zbiór podporządkowany jest pryncypium: „Bóg dopuścił, że sam wpadł w jego ręce" (Wj 21,13) i chodzi w nim o zdefiniowanie przypadkowych zabójstw. Obowiązują tu pewne reguły: należy poczekać, aż będzie możliwa pełna ocena szkód (Wj 21,18-21), chodzi nie tylko o śmierć, ale także różnego rodzaju rany (Wj 21,18-21.26-27) oraz relację pomiędzy ofiarą i jej właścicielem (Wj 21,20-21.26-27.32). W tym kontekście pełna formuła lex talionis pojawia się jednak tylko w powiązaniu z przypadkiem ciężarnej kobiety. Już sam fakt jej zastosowania w tym miejscu sugeruje, że uczestnicy bójki nie są postrzegani, jako „nieświadomi” winowajcy i, jak sądzi E. van Staalduine-Sulman ${ }^{70}$, „formuła wspomniana jest $\mathrm{w}$ tym miejscu, ponieważ jest to pierwszy przypadek użycia kryterium wiedzy i ochrony (criterion of knowledge and protecting) całkowicie niewinnej ofiary”. Walczący mężczyźni z Wj 21,18-20 - zauważa ta sama badaczka ${ }^{71}$ - obaj ponoszą odpowiedzialność, gdyż obaj są uczestnikami bójki. Właściciel niewolnika ma prawo go ukarać, ale nie może go zabić. Ciężarna kobieta tymczasem nie ma nic wspólnego z bójką. Mężczyzna, który ją uderzył, ponosi więc odpowiedzialność, gdyż miał znajomość zagrożenia. Wyjaśnia to zarazem różnicę między mężczyzną (Wj 21,18-19) i kobietą w roli

\footnotetext{
66 Por. S.A. Kaufman, The Second, s. 111-116 zwł. 112-115.

67 Ibidem, s. 112.

68 E. van Staalduine-Sulman, Between, s. 211-212.

69 Ibidem, s. 213.

70 Ibidem, s. 218.

71 Ibidem, s. 219.
} 
ofiary. Obaj walczący mężczyźni znają, a przynajmniej znać powinni ryzyko, jakie niesie ze sobą ich bójka, stąd odpowiadają za rany, które mogą być jej skutkiem. Obaj noszą ich ślady na swoim własnym ciele. W takim wypadku więc rekompensaty wymagają jedynie straty ekonomiczne. Inaczej jest, kiedy ofiarą zostaje strona nieuczestnicząca w bójce. Czemu lex talionis przywołane jest dopiero przy trzecim kazusie (po naruszeniach integralności cielesnej i niezamierzonych uderzeniach)? Pełna odpowiedź na to pytanie uzyskuje się, kiedy porównać obecne zastosowanie tej zasady z pozostałymi dwoma. Przypadek ciężarnej kobiety, to pierwszy przykład w Kodeksie Przymierza, który pozwala na wyjaśnienie w całej pełni odpowiedzialności za popełnione czyny, które naruszają czyjąś godność oraz integralność cielesną. Rolę zasady talionu w obecnym miejscu należy rozumieć jako część tzw. concatenation of thoughts (powiązania myśli) ${ }^{72}$. Poszczególne kazusy, inaczej niż w paralelach mezopotamskich, mają charakter bardziej ogólny, i tym samym obejmują szerszy wachlarz przypadków. Przykład z ciężarną kobieta nie zakłada tylko najgorszego $\mathrm{z}$ nich (śmierć płodu lub/i jego matki), ale bierze pod uwagę różne warianty związane $\mathrm{z}$ tego typu sytuacją ${ }^{73}$. W.H.C. Propp ${ }^{74}$ uważa taką wieloznaczność za original characteristic of the First Code. W odróżnieniu od prawodawców mezopotamskich, którzy tworzą bardziej detaliczne zbiory różnych przypadków, prawodawca biblijny daje dowód swojej wirtuozerii, podając małą liczbę przypadków. Poprzez ich wieloznaczność, mają one jednak zarazem szerokie implikacje dla wielu możliwych wariantów.

\subsection{Analiza lingwistyczna}

Tekst hebrajski nie rozstrzyga definitywnie o tym, ilu jest uczestników bójki. Tłumaczenie LXX (duo andres - dwóch mężczyzn; por. Peszitta) wydaje się jednak słuszne, gdyż rdzeń czasownikowy nșh Nifal dość często opisuje zmagania dwóch ludzi (Wj 2,13; Kpł 24,10; Pwt 25,1; 2 Sm 14,6; + Lb 26,9 Hifil) ${ }^{75}$. Nie wiemy też, czy kobieta brzemienna ('iššăh hārāh) ${ }^{76}$ jest tu żoną jednego z uczestników i czy angażowała się w tę bójkę (por. Pwt 25,11-12). Można więc zakładać, że obecny kazus obejmuje sobą zarówno przypadek, gdy poszkodowana jest żoną jednego z tych mężczyzn, jak i sytuacje, w których jest żoną

72 Ibidem, s. 223.

73 Ibidem, s. 224: „cover all cases of pregnant women as victims: miscarriage, harm to the newborn baby and harm to the women, including her possible death".

74 Exodus, s. 221.

75 N. Collins, Note, s. 289-301.

76 KBL, t. I, s. 243. 
kogoś nie mającego z całym zajściem nic wspólnego. Obecny kontekst sugeruje w każdym razie przypadkowość całego incydentu, a kobieta jawi się jako postronna ofiara. Kolizję opisuje rdzeń czasownikowy ngp Qal, który w obecnym miejscu ma sens „wyrządzić szkodę przez uderzenie"77. Powróci on za chwilę w opisie przypadku „uderzenia”, jakie czyjś wół zada wołu należącemu do innego człowieka. Forma liczby mnogiej wydaje się obwiniać obu uczestników, ale w opisie wyznaczającym męża kobiety, jako ustalającego wysokość odszkodowania, mowa jest o jednym tylko sprawcy (por. w. 22bA „na niego”).

Efekt uderzenia opisany jest zwrotem $w^{e} j \bar{a} s^{\prime} \hat{u} j^{e} l \bar{a} d e j h \bar{a}$. - „wyjdą (urodzą?) się dzieci (chłopcy!)". Prawodawca bierze najpierw pod uwagę tylko ten fakt, zakładając dalej, że $w^{e} l o{ }^{\prime}$ jihjeh 'āsôn, a więc dopowiada klauzulę ograniczającą ten kazus: „i nie będzie żadnego 'āsôn”. Konstrukcja zdania nie rozstrzyga więc, czy szeroko dyskutowane - o czym za chwilę - słowo 'āsôn odnosi się do matki, czy do dziecka? ${ }^{78}$ Tradycyjne przekonanie -w tym także i moje wcześniejsze rozumienie tej wypowiedzi - że chodzi tu o kazus poronienie płodu, ale bez szkód poniesionych przez matkę, musi zatem zostać przemyślane na nowo.

Pierwszy argument dotyczy rdzenia jṣ’ - „wyjść”, który można zrozumieć na kilka różnych sposobów ${ }^{79}$. Wielu egzegetów zwraca jednak uwagę na fakt, że w pierwszym i podstawowym znaczeniu, w kontekście porodu, oznacza on narodziny żywego dziecka ( $\operatorname{Rdz} 25,25-26 ; 28,28-30$; Jr 1,5; 20,18) ${ }^{80}$. W przypadkach poronienia lub śmierci tuż po urodzeniu stosuje się zaś dodatkowo derywaty słowa $m(w) t$ (Lb 12,12; Hi 3,11) lub używa się zupełnie innego i bardziej jednoznacznego rdzenia czasownikowego (škl por. $\mathrm{Rdz} 31,38$; Wj 23,26; Oz 9,14; npl w Hi 3,16; Ps 58,8; Koh 6,3) ${ }^{81}$. Na interpretację tego czasownika w sensie "poronić" w obecnym miejscu wpływ miały wspomniane paralele prawne ze starożytnego Bliskiego Wschodu. Wielu badaczy dostrzegając niejednoznaczność takiej interpretacji w przypadku zapisu biblijnego, zakładało więc, że powstał on pod wpływem tych paraleli prawnych i stąd musi mieć identyczny do nich sens ${ }^{82}$. Dzisiaj - jak zauważyliśmy - podważa się jednak taką mechaniczną zależność ${ }^{83}$. Znaleźć można także ciekawą reinterpretację

77 Ibidem, s. 630.

78 Podkreśla to m.in. V.P. Hamilton, Exodus, s. 386.

79 Por. omówienie w: C. Houtman, Exodus, t. III, s. 162-163.

80 M.in. B.S. Jackson, The Problem, s. 292; H.W. House, Miscarriage, s. 110; J.I. Durham, Exodus, s. 323; E. van Staalduine-Sulman, Between, s. 220.

81 Por. także przykłady z Ugarit w: H.W. House, Miscarriage, s. 111-112.

82 J.M. Sprinkle, The Interpretation, s. 250 i autorzy cytowani w przypisie nr 53.

83 Tak m.in. W.H.C. Propp, Exodus, s. 222. Badacz ten uważa, że poprzez dwuznaczność interpretacyjną związaną z niedopowiedzeniem (co lub kto wyjdzie z łona matki?) 
alternatywnego tłumaczenia: „przedwcześnie porodzi”. D.K. Stuart ${ }^{84}$ za najbardziej prawdopodobne uważa np. tłumaczenie: „ale ona [tj. ciężarna kobieta] nadal jest zdolna mieć dzieci i nie odniosła rany.... Dopuszcza jednak zarazem nie tylko możliwość, że urodziła dziecko/dzieci, ale i najgorszy wariant - śmierć płodu. W jego opinii zasada prawna bierze w każdym razie pod uwage przede wszystkim zdolności prokreacyjne kobiety, choć nie wyklucza definitywnie sytuacji, że szkody poniósł również sam płód.

W kontekście tej ostatniej propozycji mniej zastanawiający byłby także fakt, że prawodawca mówi tu w liczbie mnogiej jelādejhā - „jej dzieci” (PentSam ma liczbę pojedynczą). Można założyć oczywiście, że bierze on pod uwagę również kazus ciąży mnogiej (np. bliźnięta). Zdaniem wielu egzegetów może tu jednak chodzić o tzw. abstract plural, którego sens może być albo taki, jak sugeruje J.M. Sprinkle ${ }^{85}$ : „plural yldyh implying an abstract, 'child-product, fruit of the womb', or the like, an apt term for a stillborn baby", albo też jak rozumie go wspomniany już D.K. Stuart ${ }^{86}$ : „any child or children she might have”. W pierwszym proponowanym sensie rozumie go np. tłumaczenie LXX, gdyż mowa jest $\mathrm{w}$ nim o płodzie nie do końca jeszcze uformowanym (kai exelthē to paidion autēs exeikonismenon - „także poroniłaby dziecko jeszcze nie mające pełni kształtów") ${ }^{87}$. Również W.H.C. Propp ${ }^{88}$ sugeruje, jako jedną z możliwości, zrozumienia zastosowanej tu liczby mnogiej w odniesieniu do różnych etapów w procesie formowania się płodu. Inne jeszcze możliwości, to interpretacja liczby mnogiej w sensie tzw. distributive plural ${ }^{89}$ lub plural of generalisation ${ }^{90}$.

zyskuje się cały wachlarz możliwości: zdrowa matka i dziecko; śmierć lub rana matki, lecz zdrowe dziecko; zdrowa matka i ranne dziecko; śmierć lub rana matki i dziecka.

84 Exodus, s. 491.

85 The Book, s. 93; zgadza sie z nim V.P. Hamilton, Exodus, s. 385.

86 Exodus, s. 491 przyp. 135.

87 Tak tłumaczy R. Popowski, Septuaginta, s. 98. Jak zauważa tłumacz, Wulgata nie idzie za tą interpretacją, ale już św. Augustyn tak (nondum formatus), czym wpłynął na późniejszą chrześcijańską dyskusję związaną z pytaniem, od jakiego momentu należy liczyć się z zabójstwem człowieka w przypadku płodu.

88 Exodus 19-40, s. 222.

89 GKC $\$ 1240$ : „indefinite singular... when evidently only one child is thought of, though certainly in connexion with a contingency which may be repeted".

90 Joüon $₫ 136$ j: „which seem due to generalisation and to indetermination... offspring”. 
Słowo 'āsôn (ww. 22-23) ma długą historię interpretacji ${ }^{91}$. Dzisiaj zwykle rozumie się je jako „uraz fizyczny”" lub „nieszczęśliwy wypadek”93. Kwestia tego, czy oznacza on jedynie poważną ranę, czy też uraz mogący prowadzić do utraty życia, stanowi nadal przedmiot dyskusji. Zasada talionu powiązana w obecnym miejscu z tym słowem (ww. 23b-25) pozwala na szeroką gamę możliwych znaczeń. Rozumienie słowa 'āsôn w sensie : „nieszczęśliwy wypadek” ${ }^{94}$ nie do końca pasuje jednak do możliwych zastosowań przywołanej tu zasady talionu (Wj 21,24-25) ${ }^{95}$. Ponadto zakłada, że chodzi o nieintencjonalnie zadaną ranę. Poza obecnym tekstem słowo to powraca jeszcze tylko w opowiadaniu o Józefie ( $R d z$ 42,4.38; 44,29; por. jednak także hebr. tekst Syr 38,16-18; 41,9; 43,22). $\mathrm{Z}$ jego pomocą Jakub wyraża swoje obawy, co do losu swego najmłodszego syna, Benjamina, gdyby zgodzić się posłać go z pozostałymi braćmi do Egiptu. Większość egzegetów interpretuje zastosowanie tego słowa z Wj 21,22-23 w świetle tego przykładu. Problem w tym, że od strony krytyczno-literackiej, bardziej logiczne jest przyjąć, iż to obecny kazus wpłynął na zastosowanie dyskutowanego rzeczownika w opowiadaniu o Józefie ${ }^{96}$. Nie zmienia to jednak faktu, iż spojrzenie na jego użycie w Księdze Rodzaju może pomóc zrozumieć także obecne jego zastosowanie. Egzegeci sugerują trzy możliwe sensy dla słowa 'āsôn w obecnym zastosowaniu: oznacza ono „rany spowodowane przez nieznanego sprawcę" ${ }^{97}$; śmierć kobiety ${ }^{98}$ lub śmierć płodu ${ }^{99}$. W dwóch ostatnich przypadkach słusznie jest zapytać, czemu prawodawca używa rzadko spotykanego i nieprecyzyjnego w takim wypadku słowa, zamiast powiedzieć wprost „jeśli ono/ona umrze...", jak czyni to zresztą wcześniej w najbliższym kontekście (por. Wj 21,18.20) ${ }^{100}$. Możliwa sankcja: życie za życie (w. 23b) nie wyklucza najgorszego, ale też nie ogranicza do tego sensu słowa 'āsôn (ww. 24-25). W przypadku Jakuba myśleć można o różnych możliwych fizycznych zagrożeniach dla syna w trakcie podróży. Kontekst sugeruje dużą dozę emocji

91 S. Isser, Two Traditions, s. 30-45.

92 D.J.A. Clines (red.), Doctionary (dalej DCH), t. I, s. 345.

93 KBL, t. I, s. 71; W. Gesenius F. Buhl, Hebräisches, t. I, s. 83: do w. 23 „Unglücksfall, bes. Tödlicher Unfall” (por. też Józef Flawiusz, Ant, 4.33.278).

94 Tak np. C. Houtman, Exodus, t. III, s. 163: fatal injuring.

95 Stąd wniosek w przypadku takiej interpretacji może być tylko jeden - formuła została zastosowana stereotypowo, tak np. U. Cassuto, A Commentary, s. 276.

96 Słusznie zwraca na to uwagę E. van Staalduine-Sulman, Between, s. 220.

97 R. Westbrook, Lex Talionis, s. 56-57.

98 S.E. Loewenstamm, Exodus, s. 358; D.P. Wright, Miscarriage, s. 548-549.

99 B.S. Jackson, Wisdom, s. 216-220.

100 V.P. Hamilton, Exodus, s. 387. 
w sformułowaniu jego obaw. Ten właśnie aspekt podkreśla V.P. Hamilton ${ }^{101}$, wskazując, że prawodawca świadomie użył takiego „emocjonalnego” sformułowania, chcąc podkreślić nim dozę cierpienia, szok jaki wywołuje w ofierze i jej bliskich (mąż) doznane cierpienie. Jego zdaniem rzeczownik ten obejmuje swoim sensem zarówno możliwe wypowiedzi, zachowania, jak i uczucia innych osób związanych z bezpośrednią ofiarą przypadkowego incydentu.

Przy nowej interpretacji w. 22a, w której przyjmiemy, że nie chodzi o poronienie płodu, ale o dziecko, które mogło urodzić się żywe, słowo ’āsôn, użyte tu dwa razy, może odnosić się zarówno do szkód poniesionych przez płód, jak i jego matkę ${ }^{102}$. Starożytne tłumaczenia nie dają w tej materii żadnej pewności. Wulgata łączy bowiem interesujący nas rzeczownik jedynie z matką, zaś LXX z dzieckiem. Jeśli ograniczymy się wyłącznie do matki, to brak 'āsôn w w. 22 zakłada niegroźne konsekwencje poniesione przez kobietę, zaś 'āsôn z w. 23 sugeruje poważne rany $\mathrm{z}$ groźbą utraty życia włącznie. Jeśli jednak rzeczone słowo odnosi się do dziecka, to w w. 22 brak 'āsôn oznacza jedynie, że doszło do (przedwczesnego?) porodu, zaś w w. 23 chodzi o poważne urazy przedwcześnie urodzonego płodu, z poronieniem włącznie (por. w. 23b) lub dziecka, jeśli bierze się pod uwagę, że dziecko urodzi się w normalnym czasie, ale mogło ponieść jakieś szkody w wyniku opisanej wcześniej sytuacji (por. ww. 24-25). Słusznie jest więc postawić sobie pytanie, czy prawodawca nie ma tu aby na uwadze właśnie takiej szerokiej i wieloaspektowej interpretacji tego przepisu, która pozwala go aplikować do wielu różnych możliwych sytuacji? ${ }^{103} \mathrm{Wspo-}$ minany „emocjonalny” charakter spojrzenia na te wszystkie możliwości, jakie zawiera w sobie słowo 'āsôn i równie emocjonalną, a więc nie zawsze adekwatną do rzeczywistych strat, potencjalną reakcje na to, co zaszło, ma ostudzić przypomnienie zasady talionu (ww. 23b-25).

W pierwszym wypadku, a więc gdy nie doszło do fizycznego urazu, dziecko urodziło się żywe i ani jemu, ani jego matce niestało się nic, co mieści się w słowie 'āsôn, przewidziana jest jedynie grzywna. Nie jest ona zapłatą za poronienie, jak często się to interpretuje. Wydaje się być raczej rekompensatą za naruszenie nietykalności osobistej. Zapłata ta nie podlega dyskusji, co podkreśla formuła 'ānôš jēânēěs, w której formę Nifal imperfectum rdzenia ' $n s^{104}$ wzmac-

101 Exodus, s. 388 ze wskazaniem na A. Barter, The Representation, s. 243-244.

102 Stąd np. B.S. Jackson (The Problem, s. 290-297) sądzi, że chodzi tu wyłącznie o rany płodu, a S.E. Loewenstamm (Exodus 5, s. 352-360), że o rany i płodu, i matki.

103 Tak sugeruje - stawiając to pytanie - V.P. Hamilton, Exodus, s. 387. Podobnie W.H.C. Propp, Exodus, s. 222.

104 KBL, t. I, s. 800: w osnowie Nifal: „być opłaconym przez”; por. 'ôneš - „grzywna” (2 Krl 23,33). 
nia dodatkowo forma Qal infinitivus absolutus ${ }^{105}$. W konsekwencji prawodawca kładzie tym samym akcent na konieczność zapłacenie wspomnianej grzywny. W sytuacji, gdy nie byłoby żadnej szkody fizycznej, winowajca mógłby uznać, $\dot{z}$ e nie stało sie nic takiego, co wymaga rekompensaty. B. Jacob ${ }^{106}$ skupia swoja uwagę na słowie ka’ăšer, którego nie interpretuje w sensie „według tego, co (wyznaczy)", lecz zgodnie z propozycją średniowiecznych egzegetów żydowskich (Raszi, Ramban, Ralbag), w sensie ,jeśli zdarzy się, wówczas...”. Chodzi zatem, według niego o sytuację, w której nikt nie odniósł żadnej szkody, ale poród kobiety w takich okolicznościach jest publicznym poniżeniem (por. Pwt 22,19). D.K. Stuart ${ }^{107}$, zgodnie $\mathrm{z}$ sugerowanym przez siebie rozumieniem czasownika jṣ’ (,jeśli [kobieta] nadal jest zdolna urodzić dzieci” lub „jeśli dziecko nie będzie miało urazów..."), sugeruje, że chodzi tu o wyznaczenie grzywny, ale należy poczekać z ustaleniem jej wysokości (to rola męża), aż będzie można właściwie oszacować/ocenić potencjalne szkody (kobiety lub dziecka). Jeśli takie by były, to stosuje się wówczas zasadę talionu.

Widać więc, że zarówno sam sens grzywny, jak i znaczenie słowa biplilîm zależą od tłumaczenia wspomnianego już rdzenia czasownikowego jṣ’. Jeśli oznacza on narodziny żywego dziecka, jak przyjmuje już dziś większość badaczy, to grzywna ta nie może być postrzegana jako rekompensata za poroniony płód. Jedyny inny przykład nałożenia grzywny, to fałszywe, publiczne oskarżenie rzucone przeciwko kobiecie, której imputuje się brak dziewictwa podczas nocy poślubnej. Oskarżyciel, któremu udowodni się kłamstwo, zostaje skazany na zapłacenie grzywny (por. Pwt 22,13-21), gdyż „okrył niesławą dziewicę Izraela” (Pwt 22,19). Chodzi więc o dobre imię samej kobiety, jak i jej rodziny. W obecnym przypadku przyczyny mogą być podobne. Dotknięta została cudza żona, czym naruszono jej dobre imię oraz honor jej męża ${ }^{108}$. Nie wykluczone, że prawodawca uwzględnia tu także fakt „publicznego”, przedwczesnego porodu.

Wysokość grzywny wyznacza w każdym razie - tak sugeruje przynajmniej większość współczesnych tłumaczeń - mąż uderzonej kobiety i zarazem ojciec (przedwcześnie) urodzonego dziecka (w. 22b). Jego żądania nie są jednak poza kontrolą, gdyż mogłyby być zbyt wygórowane. Sprawca incydentu i wyznaczający grzywnę mąż kobiety podlegają regule opisanej jako $w^{e} n a \overline{t a n} b i$ plilîm. Problem polega jednak na tym, że rdzeń $n t n$ w swoim podstawowym znaczeniu ma sens „dawać”, ale stosowany bywa z różnymi niuansami: „pła-

105 GKC $\$ 113$.

106 Das Buch, s. 667.

107 Exodus, s. 492.

108 Tak E. van Staalduine-Sulman, Between, s. 221. 
cić” (Wj 21,19), „nałożyć” (Wj 21,23). Prawodawca może więc myśleć zarówno o tym, że winowajca ma „dać/zapłacić” grzywnę, jaki i o tym, że mąż kobiety może ją na niego „nałożyć” ${ }^{109}$. Prepozycja $b^{e}$ zwykle rozumiana jest jako tzw. $b^{e}$-pretii, odnoszące się do wysokości grzywny. Stąd forma biplilìm najczęściej rozumiana jest jako zapłata zgodna $\mathrm{z}$ wysokością ustaloną/potwierdzoną przez sędziów (polubownych) ${ }^{110}$. Ustalenie właściwego sensu dla zbitki złożonej z partykuły $b^{e} \mathrm{i}$ formy rzeczownikowej (liczba mnoga męska) rdzenia pll nie jest jednak sprawą łatwą ${ }^{111}$. W formie czasownikowej rdzeń pll Piel ma zwykle sens „rozstrzygać”, zaś pll Hitpael „modlić się, wstawiać się za”" ${ }^{112}$. Egzegeci doszukują się jednak różnych niuansów znaczeniowych, stąd sugerowane są też rozmaite alternatywne sensy w obecnym miejscu ${ }^{113}$. Sam rzeczownik w liczbie pojedynczej pojawia się jeszcze tylko dwa razy w Pwt 32,31b i Hi 31,11. Na bazie znaczenia czasownikowego dedukuje się więc sens form rzeczownikowych, i tak „pālîl odnosi się w Wj 21,22 do tych urzędników, którzy określają szkody, za które należy zapłacić w przypadkach obrażeń, a w Pwt 32,31, w pochodnym sensie, to tych wrogów, którzy mogą osądzić samych siebie, dochodząc do werdyktu uznającego wyjątkowość Skały Izraela, pelîlî w Hi 31,11.28 odnosi się do karalnych przestępstw... żądanego wyroku"114. E. Gersternberger ${ }^{115}$ zauważa jednak, że o ile rzeczownik pālîl i jego derywaty mogą w istocie mieć sens jurydyczny w takich tekstach, jak Wj 21,22; Hi 31,11.28; Iz 16,3; 28,7, o tyle w Pwt 32,31 jest on już jednak niejasny i możliwe są także inne tłumaczenia. Egzegeci w istocie proponują różne inne możliwe warianty. E.A. Speiser ${ }^{116}$ sugerował, aby w Pwt 32,31 tłumaczyć „nawet w ocenie naszych wrogów” i taki sam sens zaaplikował do Wj 21,22: „według oceny” (por. LXX: meta axiōmatos).

109 W.H.C. Propp (Exodus, 223) wskazuje na obie możliwości brane pod uwagę w żydowskiej tradycji interpretacyjnej.

110 Tak np. B. Jacob, Das Buch, s. 661; J. Scharbert, Exodus, s. 91; por. też Józef Flawiusz, Ant. 4.33.278.; b. Sanh. 111b. BT ma wariant „wypłaci ją za pośrednictwem sędziów polubownych”, natomiast BP: „da ją w obecności sędziów”. BŚP przestawia szyk w zdaniu i zmienia rozumienia całego zwrotu: „według prawa”.

111 Por. C. Houtman, Exodus, t. III, s. 162-163; W.H.C. Propp, Exodus, s. 223-225.

112 R. Schultz, pll, w: NIDOTTE, t. III, s. 627.

113 Cały ich wachlarz i różne możliwe tłumaczenia przytacza np. R. Wakely, 'nš, w: NIDOTTE, t. III, s. 466-467.

114 Ibidem, s. 628. Por. też KBL, t. II, s. 24. Takie jurydyczny sens przyjmuje dla Wj 21,22; Hi 31,11 także DCH, t. VI, s. 695, ale rozróżnia jeszcze cztery kolejne niuanse znaczeniowe dla innych przypadków.

115 R. Schultz, pll, s. 574.

116 The Stem, s. 302-303. 
Za tą interpretacją podąża C. Houtman ${ }^{117}$, który odnosi jednak zwrot biplilîm do (utraconego!) płodu. Chodziłoby o oszacowanie wysokości grzywny według tego, czy płód był już w pełni rozwinięty (w świetle $\operatorname{Rdz} 1,26$; 9,6: byłby więc obrazem Boga), czy jeszcze nie (por. LXX; Prawo hetyckie $\$ \$ 17-18$ ), oraz tego, czy mąż poszkodowanej kobiety jest już ojcem i ma przynajmniej jednego syna. Taką interpretację dopuszcza także B. Jacob ${ }^{118}$, który uważa, że kwestia grzywny może tu wiązać się z ,jakością" samego płodu, a więc oceną według zasady, czy narodzone dziecko jest zdolne do życia, czy nie i czy chodzi o chłopca lub dziewczynkę (por. Wj 21,28-32). Jego propozycja także jednak zakłada najgorszy z możliwych wariantów: poronienie. Jeśli go jednak wykluczymy, to sens „ocena” można zastosować również do męża pokrzywdzonej kobiety, który nałoży grzywnę na winowajcę według swojej oceny poniesionych szkód ${ }^{119}$. R. Westrbrook ${ }^{120}$ sugeruje $\mathrm{z}$ kolei tłumaczenie he shall pay alone, czym odpowiedzialność za zapłacenie żądanej grzywny pozostawia samemu sprawcy. A. Berlin ${ }^{121}$ powraca do tej koncepcji, sugerując, że podstawowy sens rdzenia pll zawiera się $\mathrm{w}$ słowach be held accountable/responsable/liable, co pozwala zrozumieć rzeczownikową formę w Wj 21,22 w sensie „zapłaci jako strona winna” (ang. as the culpable parts). C.M. Carmichael ${ }^{122}$ rozumie z kolei partykułę waw w zwrocie $w^{e} n \bar{a} t a n$, nie tyle w jako łącznik ,i”, ile jako alternatywę: „lub zapłaci”. W takim wypadku przepis brzmi „będzie surowo ukarany grzywną według tego, co mąż kobiety na niego nałoży lub zapłaci za pośrednictwem sędziów”. Zakłada więc możliwość polubownego zakończenia sporu lub odwołanie się do arbitrażu. Ch. Dohmen ${ }^{123}$ zachowuje tradycyjną interpretację waw, ale ostatniego zwrotu nie tłumaczy jako „sędziowie”, lecz jako „stróże”. W uwagach do tłumaczenia, ani w późniejszym komentarzu nie uzasadnia jednak swojego wyboru. Jak wi-

117 Exodus, t. III, s. 163. Taką interpretację, jako jedną z dwóch możliwych, przyjąłem także i ja w swoim komentarzu, tłumacząc „zapłaci za poronienie”; por. J. Lemański, Księga Wyjścia (NKBST II), 460. Nie wynika to jednak z, nieuzasadnionej przez krytykę tekstu, poprawki proponowanej przez K. Budde, Bemerkungen, s. 106-108. Według tego badacza poprawiona forma $b a n n^{e}$ pālìm sugeruje zastosowanie rzeczownika nēpel - „poronienie, poroniony płód".

118 Das Buch, s. 667; por. także S. Isser, Two Traditions, 43 i W.H.C. Propp, Exodus, s. 223 (ze wskazaniem na Kpł 27).

119 Tak E. van Staalduine-Sulman, Between, s. 223: „then a fine shall be required as high as the husband of the women impose upon him (the offender). He must impose it according to estimate".

120 Les Talionis, s. 58-61.

121 On the Meaning, s. 347.

122 Biblical, s. 35-36; podobnie B.S. Jackson, Wisdom, s. 226.

123 Exodus, s. 140: „und zwar durch Wächter muss er es geben”. 
dać istnieje szeroka gama możliwych interpretacji. Przytoczone opinie sugerują w zasadzie dwie podstawowe możliwości rozumienia niejasnego zwrotu. Z jednej strony może on oznaczać coś w rodzaju kalkulacji dokonanej po ujawnieniu się ostatecznych skutków uderzenia ciężarnej kobiety, a z drugiej odwołanie się to arbitrażu trzeciej strony, niezaangażowanej bezpośrednio w sprawę.

W egzegezie pojawił się jeszcze trzeci wariant. Zdaniem W.H.C. Prop$\mathrm{pa}^{124}$ dla zrozumienia analizowanego przez nas kazusu najistotniejsze jest bowiem przede wszystkim tekst Hi 31,9-11, gdzie rzeczownik pelîlîm występuje w zwrocie 'âwôn pelîlìm (BT: „zbrodnia podległa karze”; „wina podlegająca osądowi"125). Sądząc z kontekstu - wydaje się on na pierwszy rzut oka oznaczać "dokładną odpłatę" (ang. exact retribution), podobną do tej, znanej z prawa średnioasyryjskiego ( $\$ 55$ ), gdzie porywacz-gwałciciel ukarany jest takim samym odwetem. Ma zostać porwana jego żona i wydana na nierząd ${ }^{126}$. Podobny kontekst i niuans znaczeniowy ten sam zwrot ma również w Hi 31,28. Wspomniany badacz wyciąga z tego wniosek, że biplilîm w Wj 21,22 może stanowić coś opozycyjnego względem lex talionis. Dyskutowane słowo ma w jego opinii charakter prawnego dochodzenia sprawiedliwej rekompensaty, ale nie na zasadach wynikających ze wspomnianego lex talionis. Zdaniem Proppa ${ }^{127}$ można myśleć tu, że prawodawca ma tu na uwadze swoisty rewanż na żonie sprawcy. Egzegeta zakłada jednak, że chodzi o poronienie płodu oraz interpretuje 'āsôn jako śmierć kobiety, do której nie doszło. Taką możliwość interpretacji, wspomniany badacz, prezentuje jedynie jako speculation i dodaje, że rozumienie $p^{e} l \hat{l} \hat{\imath}(m) \mathrm{w}$ sensie „odwet” wynika wyłącznie $\mathrm{z}$ dwóch wspomnianych wypowiedzi z Księgi Hioba. Inne hebrajskie rzeczowniki wywodzące się od rdzenia pll nie mają już takiego znaczenia. Niejasny jest np. sens pelîlāh w Iz 16,3, gdzie rzeczownik ten stanowi paralelę względem 'esṣāh, słowa rozumianego zwykle jako „plan”, „rada” lub „postanowienie” 128 . Sugerowane w tym miejscu przez A. Berlin ${ }^{129}$ znaczenie pelîlāh - „przyjąć odpowiedzialność” nie jest przekonujące dla egzegetów. Tłumaczą oni ten hapax legomenon raczej jako "rozstrzygnięcie" 130 . H. Wildberger ${ }^{131}$ sugerował nawet, że chodzi o rodzaj azylu w sanktuarium i decyzję o jego udzieleniu podejmowaną przez strzegących

124 Exodus, s. 224.

125 Tł. A. Tronina, Księga, s. 393.

126 Por. polskie tłumaczenie w: E. Lipiński, Prawo, s. 192.

127 Exodus, s. 224.

128 KBL, t. I, s. 807: sugeruje również niejasny sens w Iz 16,3.

129 On the Meaning, s. 348.

130 W.A. Beuken, Jesaja, s. 122.134; B.S. Childs, Isaiah, s. 129.

131 Jesaja, s. 621. 
go kapłanów. Taki sens jest możliwy w kontekście zastosowania innego jeszcze rzeczownikowego derywatu rdzenia pll w Iz 28,7 (pelîlijjāhh). W obu wypadkach domniemany sens pozostaje jednak wciąż spekulatywny. W ostatnim zastosowaniu rzeczownikowych form wyprowadzanych od rdzenia pll (Ne 11,12; por. 3,25) można wysnuć wniosek, że opisuje się nim coś, co czyni sam Jhwh (por. $1 \mathrm{Sm}$ 2,25). W.H.C. Propp konkluduje, że mamy trzy możliwe znaczenia dla rdzenia pll - „kalkulować; sądzić; dokonywać arbitrażu”. Nie muszą one, jego zdaniem, sugerować trzech takich samych rdzeni o różnych znaczeniach. Niewykluczone, że stanowią jedynie niuanse znaczeniowe. Sędzia nie jest kimś, kto narzuca swoją decyzję. Ma raczej dopilnować pokoju, a ten wymaga dochowania sprawiedliwości. W tym celu musi on dokonać arbitrażu pomiędzy skonfliktowanymi stronami. Jego zadaniem jest więc ocena stanu rzeczy i kalkulacja. Propp sądzi, że interesujący nas kazus z Wj 21,22 zakłada oszacowanie cierpienia spowodowanego przez przedwczesny poród, jak i potencjalną utratę płodu. Jego zdaniem, oba te sensy mieszczą się w znaczeniu zwrotu biplilîm.

Druga część przepisu (w. 23a) zakłada sytuację, kiedy ktoś ( płód? kobieta?) doznaje jednak 'âsôn i prawodawca nakazuje w tym wypadku zastosowania zasad lex talionis (w. 23b-25). Zasadnicze wątpliwości budzi tu najpierw kwestia drugiej osoby w konstrukcji wenätattāh (ntn Qal perfectum), jak i niuans znaczeniowy czasownika nātan - „dać”. Część egzegetów uważa, że owo „ty” należy odnieść do sprawcy ${ }^{132}$. O nim była w istocie mowa wcześniej (w. 22b: $w^{e}$ nātan), ale w trzeciej osobie. W.H.C. Propp ${ }^{133}$ dowodzi nawet, że chodzi o sytuację odwetu, którego ofiarą może paść żona lub dziecko sprawcy. Taka zasada zresztą odpowiadałaby w ścisłym znaczeniu regule talionu (por. Pwt 24,16: krytyka jej zastosowania?). E. van Staalduine-Sulman ${ }^{134}$ zwraca jednak uwagę, że w takim wypadku obecne zastosowanie drugiej osoby byłoby różne od tego z Wj 21,14. Tam, w przypadku, gdy morderca szuka azylu chwytając się ołtarza, a potem zostaje mu jednak udowodnione, że dokonał morderstwa $\mathrm{z}$ premedytacją, to wspólnota ma obowiązek interweniować i oderwać go od tego ołta$\mathrm{rza}^{135}$. Nie ma więc powodów, aby inaczej rozumieć zastosowanie drugiej osoby liczby pojedynczej w obecnym miejscu. Chodzi bowiem o tę samą wspólnotę, która ma czuwać nad egzekwowaniem sprawiedliwych zasad rekompensaty.

132 Tak m.in. C. Houtman, Exodus, t. III, s. 170; por. też Y. Osumi, Die Kompositionsgeschichte, s. 101.

133 Exodus, s. 225-226. Por. też C. Houtman, Exodus, t. III, s. 165 (por. przykłady z KH $\S \$ 116 ; 210 ; 230$; prawo średnioasyryjskie $\$ 50$ ).

134 E. van Staalduine-Sulman, Between, s. 213-215.

135 Wspomniany C. Houtman (Exodus, t. III, s. 136) tak też rozumie tam zastosowanie drugiej osoby. 
Zdaniem niektórych badaczy ${ }^{136}$ złagodzenia interpretacyjnego wymaga jednak sama formuła „życie za życie” (Wj 21,23b: nepeš taḥat nāpeš). Ich zdaniem mamy bowiem do czynienia z „bardziej abstrakcyjną” zasadą „osoba za osobę”. Chodziłoby więc o „danie” odpowiedniej osoby w zamian za utraconą. Tego rodzaju praktyki były znane w innych prawach regionu (por. Kpł 24,17-18.21) ${ }^{137}$. Niemniej gradacyjny charakter zasady talionu nie pozwala wykluczyć tradycyjnego rozumienia: życie za życie.

\subsection{Wnioski}

Wnioski ${ }^{138}$, jakie nasuwają się po analizie lingwistycznej wskazują, że tradycyjna interpretacja (poronienie $\rightarrow$ grzywna + rany odniesione przez kobietę $\rightarrow$ lex talionis) wymaga nagięcia (trochę „na siłę”) sensu wielu pojedynczych słów, jak i całych zdań w Wj 21,22-23. Wszystko to po to, aby uzyskać ten domniemany sens prezentowanego tu prawnego kazusu i dopasować go do paralelnych rozstrzygnięć w prawie mezopotamskich. W związku z tym czasownik jṣ’ musi być odczytany jako najgorszy scenariusz (poronienie), choć nie ma przy nim pojawiającego się zwykle w takich wypadkach rdzenia $m w t$; ostatnie dwa wiersze (ww. 24-25) muszą być uznane jedynie za standardową formułę lub późniejszy dodatek, gdyż nie korespondują z domniemaną śmiercią kobiety (interpretacja słowa 'āsôn w sensie „śmiertelny uraz”); grzywna nałożona na sprawcę dotyczy poronienia, choć słowo to nie jest używane na opisanie rekompensaty, lecz zadośćuczynienie za publiczne pohańbienie honoru. Wszystkie te trudności wiążą się ze wspomnianym założeniem, że prawodawca biblijny ma na myśli kazus sensu stricte paralelny do prawodawstwa mezopotamskiego. Jeśli odrzucimy te założenia i skupimy uwagę jedynie na bezpośrednim kontekście (Pięcioksiąg), wszystkie te trudności łatwo jest usunąć. Analiza kontekstualna sugeruje, że sposób sformułowania przepisu intencjonalnie zakłada mnogość możliwych sytuacji wynikających z przypadku uderzenia ciężarnej kobiety. Reguła talionu odnosi się do nich wszystkich. Samo prawo nie wyklucza także najgorszego scenariusza - poronienie lub śmierć matki. Nie można jednak stwierdzić, że się do niego tylko ogranicza. Grzywna (Wj 21,22b) dotyczy tu nie tyle utraty płodu, ile raczej sytuacji publicznego dyshonoru. Rekompensata (odwet?) za poronienia, tak jak i za ewentualną śmierć kobiety, podlega regule talionu. Według tej samej zasady rozpatrywane są także wszystkie inne potencjalne szkody

136 Por. B.S. Jackson, Studies, s. 271-297; W.H.C. Propp, Exodus, s. 226.

137 J.J. Finkelstein, Ammișaduge's, s. 91-104; S.M. Paul, Studies, s. 72-77.

138 Korzystam tu także również z uwag poczynionych przez E. van Staalduine-Sulman, Between Legislation, s. 222-223. 
fizyczne (dziecka i matki). Innymi słowy płód traktowany jest w tym prawie tak samo, jak jego matka i podlega takiej samej prawnej ochronie, jak każdy inny żywy członek społeczności Izraela.

Mając na uwadze powyższą analizę, możemy zaproponować następujące tłumaczenie Wj 21,22-25:

(w. 22) Jeśli jacyś [dwaj] ludzie walcza ze soba i uderza ciężarna kobietę i ona urodzi potomstwo (dosł. dzieci), a nie będzie szkody [fizycznej], [sprawca] koniecznie zapłaci grzywnę wedtug tego, co nałoży na niego maż̇ kobiety; zapłaci/wyznaczy (sprawca/ mąż?) zgodnie z [ustaleniem] arbitrów sądowych. (w. 23) Jeśli [jest] szkoda, wówczas wyznaczysz [wedtug zasady]: życie za życie, (w. 24) oko za oko, zab za ząb, ręka za rękę, noga za nogę, (w. 25) oparzenie za oparzenie, ranę za ranę, siniec za siniec.

\section{Bibliografia}

Albright W.F., History, Archaeology, and Christian Humanism, New York 1964.

Barter A., The Representation of Speech in the Casuistic Laws of the Pentateuch. The Phenomenon of Combined Discourse, JBL 126 (2007), s. 231-249.

Berg W., Geburt, w: M. Görg, B. Lang (red.), Neues Bibel-Lexikon, t. I, Zürich 1991, s. 748-751.

Bergmann C., Childbirth as a Metaphor for Crisis. Evidence from the Ancient Near East, the Hebrew Bible, and 1QH XI,1-18 (BZAW 382), Berlin, New York 2008.

Berlin A., On the Meaning of PLL in the Bible, RB 96 (1989), s. 345-351.

Bester D., Körperbilder in den Psalmen. Studien zu Psalm 22 und verwandten Texten (FAT II/24), Tübingen 2007.

Beuken W.A., Jesaja 13-27 (HThKAT), Freiburg, Basel, Wien 2007.

Block D.I., The Book of Ezekiel. Chapters 1-24 (NICOT), Grand Rapids 1997.

Budde K., Bemerkungen zum Bundesbuch, ZAW 111 (1891), s. 106-108.

Carmichael C.M., Biblical Laws of Talion, Oxford 1986.

Cassuto U., A Commentary on the Book of Exodus, Jerusalem² 1974.

Childs B.S., Isaiah (OTL), Louisville in. 2001.

Clay A.T., Miscellaneous Inscription in the Yale Babylonian Collection (Yale Oriental Series 1), New Haven 1915.

Clines D.J.A., Job 1-20 (WBC 17), Dallas 1989.

Clines D.J.A. (red.), The Dictionary of Classical Hebrew, t. I-VIII, Sheffield 1993-2011.

Collins N., Note on the Text of Exodus XXI, 22, VT 43 (1993), s. 289-301.

Dohmen Ch., Exodus 19-40 (HThKAT), Freiburg, Basel Wien 2004.

Dozeman Th.B., Exodus (ECC), Grand Rapids, Cambridge 2009.

Durham J.I., Exodus (WBC 3), Waco 1987.

Ellington J., Miscarriage or Premature Birth, Bible Translator 37 (1986), 334-337.

Finkelstein J.J., Ammișaduge's Edict and the Babylonian „Law Codes”, JCS 15 (1961), 91-104. 
Fischer G., Jeremia 1-25 (HThKAT), Freiburg, Basel, Wien 2005.

Foskett M., Birth, w: K.D. Sakenfeld (red.), The New Interpreter's Dictionary of the Bible, t. I, Nashville 2006, s. 470-471.

Frevel Ch., Wischmeyer O., Menschensein. Perspektiven des Alten und Neuen Testaments (NEB- Themen 11), Würzburg 2003.

Frevel Ch., Die Entstehung des Menschen. Anmerkungen zum Vergleich der Menschwerdung mit der Käseherstellung in Ijob 10,10, BN 130 (2006), s. 45-57.

Gerstenberger E., Fabry H.J., pll, w: G.J. Botterweck in. (red.), Theological Dictionary of the Old Testament, Grand Rapids, t. XI, Cambridge 2001, s. 567-578.

Gesenius' Hebrew Grammar, red. E. Kautzsch, A.E. Cowley, Oxford 1910.

Gesenius W. Buhl F., Hebräisches und aramäisches Handwörterbuch über das Alte Testament, t. I, Berlin ${ }^{18} 1987$.

Greenberg M., Ezechiel 1-20 (HThKAT), Freiburg, Basel, Wien 2001.

Grimm M., „Dies Leben ist der Tod”. Vergänglichkeit in den Reden Ijobs - Entwurf einer Textsemantik (ATSAT 62), St. Ottilien 1998.

Habel N.C., The Book of Job (OTL), Philadelphia 1985.

Häusl M., Bedecken, Verdecken, Verstecken. Studie zur Valenz althebräischer Verben (ATSAT 59), St. Ottilien 1997.

Häusl M., Bilder der Not. Weiblichkeits- und Geschlechtermetaphorik im Buch Jeremia (HBS 37), Freiburg 2003.

Häusl M., Die Zeit der Schwangerrschaft, w: S.Ö. Steingrimsson, K. Olason (red.), Literatur- und sprachwissenschaftliche Beiträge zu altterstamentlichen Texten. Symposion in Hólar í Hjaltadal 16.-19. Mai 2005. Fs. W. Richter (ATSAT 83), St. Otillien 2007, s. 69-85.

Häusl M., Geburt - Kampf um Leben und gegen den Tod. Alttestamentlichen Vorstellungen und Rituale für Mutter und Kin dam Anfang des Lebens, w: B. Heininger (red.), An den Schwellen des Lebens. Zur Geschlechterdifferenz in Ritualen des Übergangs (Geschlecht - Religion - Symbol 5), Münster 2008, s. 119-134.

Häusl M., Auf den Leib geschriben. Körperbilder und--konzepte im Alten Testament, w: Ch. Frevel (red.), Biblische Anthropologie. Neues Einsichten aus dem Alten Testament (QD 237), Freiburg, Basel, Wien 2010, s. 134-163.

Hamilton V.P., Exodus. An Exegetical Commentary, Grand Rapids 2011.

Hossfeld F.L., Zenger E., Psalmen 51-100 (HThKAT), Freiburg, Basel, Wien 2000.

Hossfeld F.L., Zenger E., Psalmen 101-150 (HThKAT), Freiburg, Basel, Wien 2008.

House H.W., Miscarriage or Premature Birth: Additional Thoughts on Exodus 21,22-23, WTJ 41 (1978), s. 108-123.

Houtman C., Eine schwangere Frau als Opfer eines Handgemenges (Exodus 21,22-25): Ein Fall von Sellvertretender Talion im Bundesbuch?, w: M. Vervenne (red.), Studies in the Book of Exodus: Redaction - Reception - Interpretation (BETL 126), Leuven 1996, s. 381-397.

Houtman C., Exodus (HCOT), t. III, Leuven 2000.

Isser S., Two Traditions: The Law of Exodus 21,22-23 Revisited, CBQ 52 (1990), s. 30-45. Jackson B.S., The Problem of Exodus xxi 22-5 (ius talionis), VT 23 (1973), s. 273-304. Jackson, B.S. Studies in Semiotics of Biblical Laws (JSOT.S 314), Sheffield 2000. 
Jackson. B.S., Wisdom - Laws: A Study of the „Mishpatim” of Exodus 21,1-22,16, Oxford 2006.

Jacob B., Das Buch Exodus, Stuttgart 1997.

Joüon P., Muraoka T., A Grammar of Biblical Hebrew, t. I-II, Roma 1993.

Kaiser O. (red.), Texte aus der Umwelt des Alten Testament, t. II/1, Gütersloh 1982.

Kaufman S.A., The Second Table of the Decalogue and the Implicit Categories of Ancient Near Eastern Law, w: J.H. Marks, R.M. Good (red.), Love and Death in the Ancient Near East. Fs. M.H. Pope, Guilford 1987, s. 111-116.

Kilmer A.D., The Brick of Birth, JNES 46 [1987], s. 211-213.

Kline G., Lex Talionis and the Human Fetus, JETS 20 (1977), s. 193-201.

Koehler L., Baumgartner W., Stamm J.J. (red.), Wielki słownik hebrajsko-polski i aramejsko-polski Starego Testamentu, t. I-II, Warszawa 2008.

Kunderewicz C., Najstarsze prawa świata, Łódź 1972.

Kuśmirek A., Hebrajsko-polski Stary Testament. Pięcioksiąg. Przekład interlinearny z kodami gramatycznymi, transliteracją oraz indeksem rdzeni, Warszawa 2003.

Lemański J., Opis stworzenia jako conditio humana $w$ Rdz 2,7?, ŚSHT 39/1 (2006), s. $5-24$.

Lemański J., Księga Wyjścia (NKBST II), Częstochowa 2009.

Lemański J., Księga Wyjścia (PKB), Tarnów 2012.

Lemański J., Księga Rodzaju rozdziały 11,27-36,43 (NKBST I/2), Częstochowa 2014.

Levine B.A., Numbers 1-20 (AB 4), New York 1993.

Lipiński E., Prawa bliskowschodnie w starożytności. Wprowadzenie historyczne (SHB 2), Lublin 2009.

Loewenstamm S.E., Exodus xxi 22-25, VT 27 (1977), s. 352-360.

Łach S., Księga Wyjścia (PŚST I/2), Poznań 1962.

Osumi Y., Die Kompositionsgeschichte des Bundesbuches Exodus 20,22-23,33 (OBO 105), Freiburg 1991.

Parchem M., Aborcja w Starym Testamencie, w: W. Chrostowski, B. Strzałkowska (red.), Patrzymy na Jezusa, który nam w wierze przewodzi. Fs. J. Łach, Warszawa 2012, s. 485-509.

Paul S.M., Studies in the Book of the Covenant in Light of Cuneiform and Biblical Law (VT. S 18), Leiden 1970.

Philip T.S., Menstruation and Childbirth in the Bible: Fertility and Impurity (Studies in Biblical Literature 88), New York 2006.

Popowski R. (tł.), Septuaginta, Warszawa 2014.

Priotto M., Esodo, Milano 2014.

Propp W.H.C., Exodus 19-40 (AB 2A), New York 2006.

Rogers C.L., šōr, w: W.A. VanGemeren (red.), New International Dictionary of the Old Testament Theology and Exegesis, London 1997, t. IV, s. 249-250.

Roth M.T. (red.), Law Collections from Mesopotamia and Asia Minor (SBL. WAWS 6), Atlanta 1993.

Scharbert J., Exodus (NEB), Würzburg 1986.

Schultz R., pll, w: W.A. VanGemeren (red.), New International Dictionary of the Old Testament Theology and Exegesis, London 1997, t. III, s. 627-628. 
Seebass H., Numeri. Kapitel 10,11-22,1 (BK IV/2), Neukirchen-Vluyn 2003.

Seybold K., Die Psalmen (HAT I/15), Tübingen 1996.

Speiser E.A., The Stem PLL in Hebrew, JBL 82 (1963), s. 301-306.

Sprinkle J.M., The Interpretation of Exodus 21,22-25 (Lex Talionis) and Abortion, WTJ 55 (1993), s. 233-253.

Sprinkle J.M., The Book of the Covenant: A Literary Approach, Sheffield 1994.

Staalduine-Sulman E. van, Between Legislation and Linguistic Parallels: Exodus 21,22-25 in its Context, w: R. Roukema (red.), The Interpretation of Exodus (CBET 44). Fs. C. Houtman, Leuven, Paris, Dudley 2006, s. 207-224.

Stępień M. (tł.), Kodeks Hammurabiego, Warszawa 2000.

Stol M., Birth in Babilonia and the Bible. Its Mediterranean Setting (Cuneiform Monographs 14), Groningen 2000.

Stuart D.K., Exodus (NAC 2), Nashville 2006.

Tronina A., Księga Hioba (NKBST XV), Częstochowa 2013.

Volk K., Vom Dunkel in die Helligkeit. Schwangerschaft, Geburt und frühe Kindheit in Babylonien und Assyrien, w: V. Dasen (red.), Naissance et petite enfance dans l'Antiquité (OBO 203), Freibourg 2004, s. 71-92.

Wakely R., 'nš, w: W.A. VanGemeren (red.), New International Dictionary of the Old Testament Theology and Exegesis, London 1997, t. III, s. 466-467.

Westrbrook R., Lex Talionis and Exodus 21,22-25, RB 93 (1986), s. 52-69.

Wildberger H., Jesaja. Kapitel 13-27 (BK X.2), Neukirchen-Vluyn²1989.

Wright D.P., Miscarriage, Talion, and Slave Injury in the Covenant Code and Hammurabi's Laws, w: J. Stackert in. (red.), Gazing on the Deep: Ancient Near Eastern and Other Studies. Fs. Tzvi Abusch, Bethesda 2010, s. 539-564.

Zeller D., Geburtsankündigung, w: w: M. Görg, B. Lang (red.), Neues Bibel-Lexikon, t. I, Zürich 1991, s. 751-753. 